DANMARKS GEOLOGISKE UNDERS $\emptyset$ GELSE

II. Rackke. Nr. 102

Geological Survey of Denmark. II. Series. No. 102

\title{
Contributions to the interpretation of the \\ Fennoscandian Border Zone
}

\author{
BY \\ J. C. Baartman and Ole Bruun Christensen \\ DANSK SAMMENDRAG \\ Bidrag til fortolkningen of \\ Den fennoskandiske Randzone
}

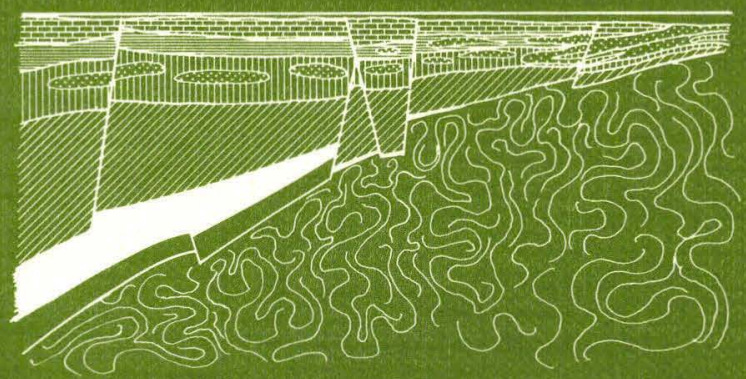

1 kommission hos C. A. Reitzels Forlag. Kobenhavn 1975 
Danmarks Geologiske Undersøgelse. II. Række. Nr. 102

Geological Survey of Denmark. II. Series. No. 102

\section{Contributions to the interpretation of the Fennoscandian Border Zone By \\ J. C. Baartman and Ole Bruun Christensen}

Dansk sammendrag:

Bidrag til fortolkningen af Den fennoskandiske Randzone

I kommission hos C. A. Reitzels Forlag København 1975 
D. G. U. II. rk. nr. 102

er sat med Monotype Times

og trykt i 1200 eksemplarer

hos Andelsbogtrykkeriet i Odense.

Klicheerne er fremstillet af

Tutein \& Koch.

Bogen er trykt på ekstraglittet specialtryk

250-41, $120 \mathrm{~g}$ fra

a/s De forenede Papirfabrikker.

ISBN 8742106400

With 4 plates

Date of publication: 1975-03-15 


\section{Contents}

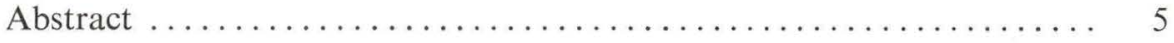

Some results of the interpretation of seismic data in the Kattegat, S. Øre-

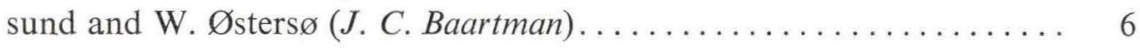

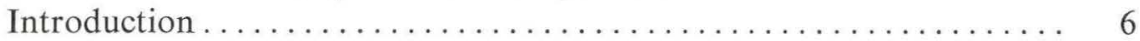

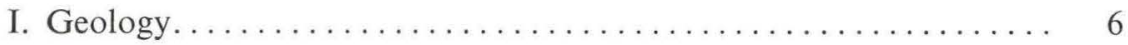

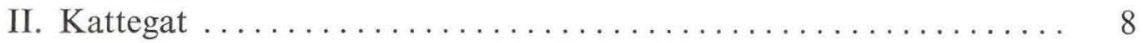

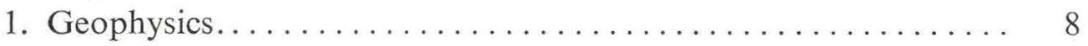

2. Reflecting horizons. ..................... 10

3. Regional setting of the Kattegat area ............... 11

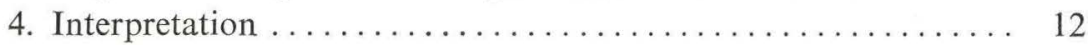

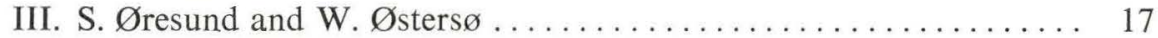

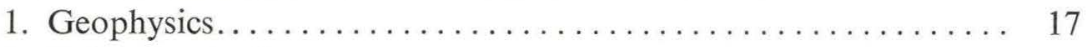

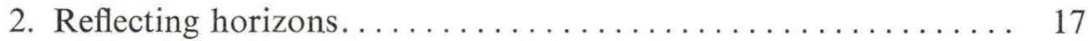

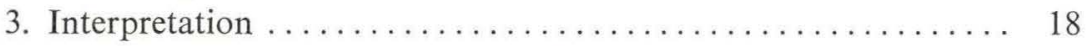

Geological outlines of the Fennoscandian Border Zone (Ole Bruun Chris-

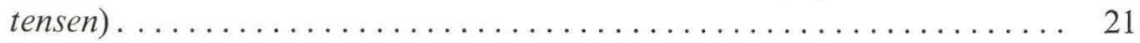

General geological outline of the area ................. 21

Some structures related to the Vendsyssel High............... 25

Structures in the northern Kattegat area................ 26

Structural outlines from the southern Kattegat to the western Baltic Sea 28

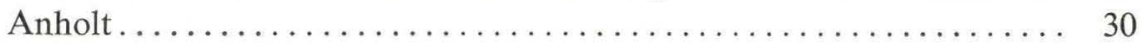

Geological models related to the area $\ldots \ldots \ldots \ldots \ldots \ldots \ldots \ldots . \ldots . \ldots 34$

Dansk sammendrag. . . . . . . . . . . . . . . . . . . . . . 39

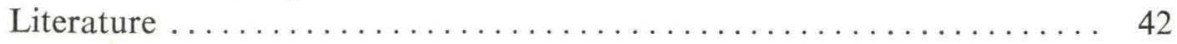


Danish geographical terms

Danmark

Helsingør

Jylland

Kattegat

Sjælland

Skagen

Skåne

Sverige

Øresund

Østersøen
Corresponding geographical terms in English

Denmark

Elsinore

Jutland

Cattegat

Zealand

the Skaw

Scania

Sweden

the Sound

Baltic Sea 


\section{Abstract}

The interpretation of reflection seismic data in the Kattegat has revealed the combined effect of tectonic movements which took place from Pre-Jurassic through recent times.

A continuation of the Fennoscandian Border Zone in Scania occupies a broader belt of more deep-seated basement-related fault blocks in the Kattegat area, but fades away towards NW. A mainly Jurassic sill striking SSW from Anholt separates the Kattegat area in partially open basins of Cretaceous deposition. In the Øresund several large north-northwest striking basementrelated faulted blocks appear to be associated with the tectonics of the Fennoscandian Border Zone.

The most prominent features relating to the structures and the geological history of the Fennoscandian Border Zone have been outlined.

Some details connected with the Pre-Quaternary outcropping for the area have been evaluated. Katholm-erratics containing "Cyrena" fossils from the Kattegat area are not of Lower Oligocene age, but from Upper Jurassic and are most probably originate from the Anholt area.

One of some structural models for northwestern Europe has been advanced for verification. Parts of the Fennoscandian Border Zone have perhaps been affected by large-scale dextral fractures. 


\title{
Some results of the interpretion of seismic data in the Kattegat, S. Øresund and W. Østersø
}

\author{
J. C. Baartman
}

\section{Introduction}

The areas formed by the shallow waters of the Kattegat, the southern Øresund and western Østersø have been interpreted seismically for the main part, but the mapping of all the geological horizons has not been completed. This report summarizes the results of seismic investigation in these areas at its present stage.

The interpretation is mainly based on exploratory reflection work, which was carried out by several contractors on behalf of the Danish American Prospecting Company (D.A.P.Co.) in the period 1946-1957, and of Gulf Oil Company of Denmark Ltd. during 1957-1969.

In addition, the results of refraction surveys which were occasionally carried out by one party in the North Jylland Salt Dome Province in the periods 19391940 and 1946-1952 could be used for velocity information in regions with shallow, high speed material.

Bouguer gravity maps (Gulf Oil Co. of Denmark, 1938-1940 and 1946-1949) and Residual Gravity Maps of the land areas, which were interpreted by Dr. S. Hammer of the Gulf Research and Development Co., were useful in examining the Pre-Zechstein section and in extending known structural trends.

The geological interpretation is based on major geological markers which were identified in the deep tests of Frederikshavn No. 1 (Vendsyssel), Gassum No. 1 (N. Jylland) and the more recent Rønde No. 1 (S. Djursland) and Ørslev No. 1 (Falster) wells as the main reflecting horizons. Velocity functions were calculated in the cases of the Skagen No. 1 well (N. Vendsyssel) and the Slagelse No. 1 well (S. Sjælland) by means of computer, since no well-velocity logs or surveys of these wells were available.

\section{Geology}

The area covered by the seismic investigation extends from Vendsyssel through the Kattegat and the Øresund towards the island of Møn. Geologically these areas occupy the northern and southern parts of the Danish Embayment, which 
is situated at the W. flank of the Fennoscandian Border Zone, but they also extend over parts of the Ringkøbing-Fyn-Falster Uplift.

These structural elements are briefly described below.

\section{The Fennoscandian Border Zone}

This Border Zone forms a tectonically disturbed area which acted as a buffer zone between a mainly subsiding Danish Embayment and a more stable Fennoscandian Shield. It stretches from the Skagerrak through the Kattegat and Scania towards Bornholm.

In Scania the Border Zone is marked by large N.W. striking fault blocks. Towards N.W. into the Kattegat and the Skagerrak this marked boundary fades away.

\section{The Danish Embayment}

S.W. of the Border Zone follows the Danish Embayment which includes the Øresund Trough and the Sjælland Embayment. The Øresund is characterized by several large N. to N.W. striking basement-related fault blocks of the Lower Palaeozoic section which appear to be associated with the tectonics of the Fennoscandian Border Zone.

The sedimentary sequence of the Lower Palaeozoic section in Sjælland consists of rocks of Cambrian, Ordovician and Silurian age whose thickness increases in the area between Sjælland and Scania. Since the deposition of Permian sediments which rest unconformably on the Lower Palaeozoic section, the Embayment has had the character of a depositional area. Permian sediments are present throughout a major part of the Embayment. The section above the Permian Zechstein is influenced by salt tectonics which gave rise to the formation of piercement salt domes, salt anticlines and interdomal salt structures.

The Embayment underwent a major subsidence during the main part of the Mesozoic, when the Fennoscandian Shield formed an important source for clastic material. In general the rate of sedimentation seems to have been able to keep pace with the varying rate of sinking, which ceased partially during the Muschelkalk.

Sedimentation within the Danish Embayment continued until toward the beginning of the Upper Cretaceous time, when it ceased to function as a major depositional area.

Towards the S.E. the Embayment merges into a deep part of the Polish Basin and towards the N.W. it continues into the North Sea.

\section{The Ringkøbing-Fyn-Falster High}

The Ringkøbing-Fyn-Falster High borders the S. side of the Danish Embay- 
ment and is a complex structure of basement horsts and grabens. The most elevated parts of the uplift seem not to have been covered by Lower Permian sediments, and the Permian Zechstein has been eroded off or never deposited over these areas. The Jurassic section is absent or thin over a main portion of this basement-high while the thickness of the Lower Cretaceous is strongly reduced. Since Upper Cretaceous time this feature has been relatively stable.

\section{Kattegat}

\section{Geophysics}

The reflection seismic work in the Kattegat was carried out by Western Geophysical Co. on behalf of Gulf Oil Co. of Denmark Ltd. An outline of the location of the lines, which were shot during several surveys, is shown in Plate 1.

In 1963 Western Geophysical Co. started a first program including the lines numbered $1 \mathrm{E}-10 \mathrm{E}$ using a single-fold coverage technique. These traverses total $290 \mathrm{~km}$ in the area (Plate 1). Analog equipment, utilizing frequency variant filtering, automatic volume control, and trace mixing were used for the recording. The results, which were transcribed into continuous sections, were of poor quality throughout most of the area.

An additional program was started in 1964 during which period the lines numbered 11E-19E were shot, covering about $450 \mathrm{~km}$ (Plate 1). A recording technique was used utilizing short $(600 \mathrm{~m}-0-600 \mathrm{~m})$ and long split spreads (1200 m-0-1200 m) which were laid out in such a way that enough CDPcoverage could be obtained to process up to 4-fold composite sections. The quality of these 4-fold composite data was much improved especially in the S.W. and W. parts of the area.

The analog recordings of some of these lines were reprocessed digitally in 1967 using deconvolution after 400\% stacking, automatic volume control and a time variant filter. For the play-back a filter ranging from 7.5 to $40 \mathrm{~Hz}$ was used. Velocity scans based on N.M.O.-estimates which were printed on these sections at regular intervals were useful in areas with a shallow basement.

Western Geophysical Co. also shot velocity profiles at two locations along these lines, which were later displayed in $\mathrm{X}^{2}-\mathrm{T}^{2}$ charts. Depth calculations within the Kattegat area are heavily dependent upon these velocity-plots.

During 1967 the NE-directed lines numbered 32E-37E were shot (Plate 1). 
These lines total about $315 \mathrm{~km}$ in the area. For the recording, a technique was used to obtain 6-fold or stacked seismic sections with split spreads (1200 m-0 $1200 \mathrm{~m}$ ) and a filter ranging from 5 to $100 \mathrm{~Hz}$. The recordings were processed by means of deconvolution after stacking and a time-variant filter ranging from 5-60 Hz. These continuous 6-fold sections featured the same type of velocity analyses as the previous 4-fold sections. The data-quality of these surveys was the best in the area, especially in the W. and S.W. parts.

In N. Jylland some refraction lines were used in order to distinguish between the refraction marker of the "basement", having a velocity ranging between $5900 \mathrm{~m} / \mathrm{sec} .-6100 \mathrm{~m} / \mathrm{sec}$, and a $5600 \mathrm{~m} / \mathrm{sec}$. marker which may represent a dolomitic facies of the Zechstein, downdip from the apex of the "basement"high in N. Jylland. These lines were shot by GR \& DC seismic party No. 32 in 1951 and 1952 for the Danish American Prosp. Co. The refraction spreads consisted of 24 detectors, 1 detector / trace, spaced $100 \mathrm{~m}$ apart, resulting in an over-all line-length of $2300 \mathrm{~m}$.

In order to tie the marine seismic data into the Frederikshavn No. 1 well, much of the onshore single-fold reflection seismic work was used. These lines were shot by S.S.L-party 260 in 1965, also for Gulf Oil Co. of Denmark Ltd., using analog recording equipment with a filter ranging from $4-38 \mathrm{~Hz}$ and automatic gain control. Some of these continuous single-fold displays were especially useful in the areas of Vendsyssel and N. Jylland for correlation of the deepest reflectors, which were identified in the refraction data.

It was also possible to use some shallow sparker sections from the University of Stockholm which were kindly contributed by Dr. N. Schröder of the University of Aarhus. These lines were recorded in the period 1968-1971. The continuous shallow seismic sections were useful in areas with a thick Pleistocene and shallow basement along the Swedish S. West coast. One of these profiles (689) is shown in Plate 1.

In general the quality of the reflection data was best in the W. and S. portion of the Kattegat. A thick sandy deltaic deposition during a large part of Mesozoic times probably contributed to decreasing resolution of the deeper-seated reflectory data towards N.E. and S.E. in the area.

In order to outline the large-scale structural events more accurately a more intense profiling would be needed throughout most of the Kattegat area. 


\section{Reflecting horizons}

Four major geological markers were identified and correlated wherever possible. These horizons are:

The approx. Base of Upper Cretaceous. This horizon is associated with the boundary between Upper Cretaceous chalk and limestone and underlying Lower Cretaceous claystone (in Rønde No. 1 respect. approx. $4350 \mathrm{~m} / \mathrm{sec}$. and $3200 \mathrm{~m} / \mathrm{sec}$.). It is not identical with the chronostratigraphical boundary between Upper and Lower Cretaceous. In the Frederikshavn No. 1 well this horizon corresponds approximately to the transition between Turonian shale and Santonian chalk.

Except in areas with thick near-surface sand deposits from the Pleistocene, this reflector is continuous and correlations are good throughout most of the area. Pre-Quaternary outcrops of this horizon (Plate 1) are based solely on information from the shallow seismic sections.

The approx. Top of Triassic. The second most continuous seismic event is associated with the approximate top of the Triassic formation. This horizon provides a strong reflector throughout most of the western and southern portions of the Kattegat area, when not disturbed by faulting.

Subsurface control at the Rønde No. 1 and Gassum No. 1 wells indicates that this horizon corresponds approximately with the Rhaetic formation: a marine and deltaic deposition in this area, which in N. Jylland and the Kattegat is developed as a predominantly sandy facies.

The approx. Base of Triassic. The Base of Triassic horizon reflector is associated with the boundary between the basal Triassic sandstone and claystone and the Zechstein rocksalt. Towards the N.E., where the Zechstein formation passes into the marginal facies of the N. Jylland-Sjælland Zechstein basin, this reflector becomes discontinuous to non-existent.

The approx. Base of Zechstein. A continuous seismic event in the S.W. part of the Kattegat is identified as coming from the Base of the Zechstein evaporite sequence, which in the Rønde No. 1 well is underlain by Rotliegendes sandstone.

A seismic horizon associated with the basement was locally recognized.

A refraction marker having a velocity range of 5900 to $6100 \mathrm{~m} / \mathrm{sec}$. has been identified with the approximate top of the Pre-Cambrian schist at the Frederikshavn No. 1 well. 
In areas outside the salt basins, i.e. mainly on Vendsyssel and the northern portion of the Kattegat area, the Pre-Cambrian horizon, when shallow seated, is associated with a strong event. Towards E. and N.E. of the area this horizon probably corresponds to the "near basement".

The approx. Base of Upper Cretaceous and the approx. Top of Triassic horizons have been mapped in two-way time together with their interval. On account of the limited time available for drafting, a map has been prepared showing the generalized structural configuration in the Kattegat area which is shown in Plate 1.

\section{Regional setting of the Kattegat area}

A large portion of the Kattegat area is regarded as belonging geologically to the marginal area or Border Zone between the Fennoscandian Shield in the N.E. and the Danish Embayment in the S. This Border Zone is connected with Scania and S. Sweden which areas are markedly disturbed by tectonic events.

Towards the N., the Kattegat area passes into the eastern part of the Skagerrak, which according to the seismic investigations of Dr. T. Flodén of the University of Stockholm (1973) formed a part of the Border Zone from the Rhaetic until the beginning of Upper Cretaceous time. According to Dr. Flodén a sub-Cambrian peneplain dips from a depth of 100-150 m close to the W. coast of Sweden to $1314 \mathrm{~m}$ at the Frederikshavn No. 1 well. Major faults between the W. coast of Sweden and Vendsyssel are very probably absent.

At the S. side of the Kattegat area the Permian deposition marked the beginning of the formation of the Danish Embayment, which underwent its strongest subsidence during Bunter time. In Jylland the greatest sedimentary thickness of the Embayment is found at the Fjerritslev No. 2 well at about $98 \mathrm{~km}$ from the Border Zone.

Towards the S.E. the Embayment reaches its greatest depth N.W. of Sjælland where the deepest reflector of the Base of Zechstein was found at a depth of about $5.0 \mathrm{~km}$. The deviation of the WNW-striking direction of the Embayment from the N.W.-striking trend of the Fennoscandian Border Zone is found again in the tectonic trends which intersect the Kattegat area.

The interpretation of the present seismic data shows that the main tectonic events in this area are situated near the northern margin of the Danish Embayment rather than within the Border Zone, and that these events are the results of several tectonic phases. 


\section{Interpretation}

The seismic map of the Kattegat area (Plate 1) shows a generalized configuration of the main fault zones, some of which were active during long periods. The approx. Base of Upper Cretaceous reflector has been contoured regionally to outline the main structures, and apparent dips are marked in the areas where this horizon became too ambiguous to map. It can be seen from this map that the main structural movements took place near the peripheries of the Embayment. Faulting in the N. portion affected mainly the "basement" and probably the Lower Palaeozoic section in the E. portion.

The Near Basement. The horizon associated with the Pre-Cambrian forms a shallow denudation surface in the northernmost parts of the area.

According to the present seismic data this zone of shallow Pre-Cambrian stretches approximately from Vendsyssel towards the island of Anholt.

Towards the S.W. it dips down below younger Palaeozoic rocks, accompanied by faulting.

N.W. of the island of Anholt, the Pre-Cambrian is about $1.3 \mathrm{~km}$ deep in a section of line 33E (Plate 2, fig. 1), while N.E. of Djursland it reaches a depth of about $5.2 \mathrm{~km}$.

Basement-related fault blocks also occur in the shoal area and along the W. coast of Sweden, but are of a small scale. According to Bouguer gravity many of these structures may have a N.E.-striking trend, especially in the vicinity of the island of Læsø.

A strong reflector along the W. coast of Sweden, probably associated with a sub-Cambrian erosion surface, dips regionally towards the S.W., interrupted by graben-structures and normal faulting.

Off the S.W. coast of Sweden and S. of the shoal Store Middelgrund, faults are present which probably border tilted blocks of the "near basement" horizon.

According to investigations of Dr. N. A. Mörner of the Geological Survey of Sweden (1969), other shoals such as Groves Flak, Lille Middelgrund and Koralgrunden appear to contain Pre-Cambrian rocks close to the surface and may therefore represent uplifts.

South of Store Middelgrund these faults were probably activated by Pre- or Intra Jurassic movements during the Early Kimmerian orogeny, since a major displacement of the Triassic section is shown.

A continuation of these horst and graben structures into S. W. Sweden seems very likely but the seismic coverage N. of Anholt and the shoal area along the W. coast of Sweden is too scarce to outline these structures accurately.

A small basin enclosed by the Hallandsåsen and the Kullen "basement" uplifts, as well as by the faults bordering these "highs", continues offshore. 
The basement fault at Hallandsåsen is offset along the W. coast of Sweden, probably by the NE-striking fault.

Faulting of the "near basement" occurs S. and E. of Anholt.

A large W.N.W.-striking fault S. of Anholt is bordered by a persistent basement "high" along its S. side, which forms a "horst"-type structure over which the Cretaceous and Jurassic formations are regionally absent (Plate 1).

The Bouguer gravity maps were very useful in areas where seismic coverage was scarce. In general the gravity anomalies correspond with the main structural trends of the reflection seismic data in areas with a shallow basement. A marked gravity-low East of Anholt corresponds with a NE-SW trending marginal trough.

The approx. Base of Zechstein and the approx. Base of Triassic. The interval enclosed between the Base of Triassic and the Base of Zechstein horizons is mainly present in the S.W. and the S. portions of the Kattegat area. Since these horizons have not been mapped until now, information concerning the Zechstein formation has been obtained directly from the seismic sections.

In W. Djursland, where the Zechstein formation still has a salt facies, its interval is regionally rather thin, but reaches a thickness of more than $1170 \mathrm{~m}$ $\mathrm{N}$. of this area, at the location of a large structure of the Upper Cretaceous formation (.260 sec., Plate 1).

Salt movement is locally reflected in the Upper Cretaceous formations. However, other tectonics, probably mainly resulting from the Late Kimmerian orogeny, must have contributed in shaping these structures.

Further N. E. the Zechstein formation thins out and is absent in the area of high basement uplift. Some approximate up-dip limits of the N. Jylland-Sjælland salt basin are traced in the 6-fold seismic data and are marked on the map (Plate 1). The Zechstein formation is largely affected by the main WNWstriking displacements. In the southernmost portion of the Kattegat where the Zechstein interval is more deep-seated no major deformations due to salt tectonics occur. It is therefore likely that the Zechstein formation consists mainly of marginal facies throughout a large part of the Kattegat where dolomite and anhydrite can be expected.

The Base of Zechstein horizon dips regionally towards the axial part of the Embayment.

W. of Anholt this horizon is about $1.8 \mathrm{~km}$ deep and reaches a depth of $5.0 \mathrm{~km}$ N. of Sjælland.

In general no major anticlinal structures are found at the Base of Zechstein and its dip is only locally broken by the largest faults.

In the S. portion of the Kattegat area more independent faults at the Base 
of Zechstein are probably related to introductory movements, which resulted in the development of the Embayment.

Towards the N. where the Permian begins its onlap of the older Palaeozoic formations, anomalies occur at the Base of Zechstein.

The approx. Top of Triassic. The thick Triassic sequence of the Embayment continues in the $\mathrm{S}$. portion of the Kattegat.

Where the "basement" horizon reaches its maximum elevation in the N. and N.E. parts of the area, it is locally directly overlain by a reduced Triassic section.

The Triassic formation wedges out on the "near basement" towards the West coast of Sweden, where it is probably mainly preserved in local grabentype structures.

Throughout a large portion of the Kattegat area the NW-SE structural trend of the Upper Cretaceous formation is also a main trend of the Top of Triassic horizon, except towards the N. where this trend becomes E-W.

Regionally the Triassic thickness is much reduced in areas of high basement uplift along the Border Zone of the Kattegat. The large NW-SE trending displacements affected the Triassic formation to a large extent but minor faulting also occurs within the Triassic.

Off the S.W. coast of Sweden and S. of the shoal Store Middelgrund two fault examples are present bordering tilted blocks at the "near basement" horizon. These faults caused a main displacement within the Triassic while the Jurassic formation was less affected. In these cases syn-sedimentary movements probably started before Jurassic or Intra-Jurassic time, which period of activity can also be found in S.W. Sweden where similar "basement" movements are reported to have been activated during the Early Kimmerian (Rhaetian) orogeny.

The approx. Base of Upper Cretaceous. During the main part of the Jurassic period the Kattegat formed locally an important area for sedimentation.

The interval enclosing the Lower Cretaceous and Jurassic formations is regionally thickened in the Kattegat, in comparison with its thickness in areas within the southern part of the Embayment.

$\mathrm{N}$. of Sjælland this interval varies regionally between $450-550 \mathrm{~m}$, while locally it reaches thicknesses of more than $750 \mathrm{~m}$ in the $\mathrm{W}$. portion of the Kattegat and in the vicinity of the Øresund (1000 m; see Larsen et al. 1965).

It is, however, difficult to differentiate the Jurassic and Lower Cretaceous formations within this interval by the present seismic data. An unconformity, probably associated with the base of Lower Cretaceous was locally recognized.

The local increase in the interval enclosing the Lower Cretaceous and Jurassic formations, for example in the NW. portion of the Kattegat, is remarkable. 
These areas of thick deposition, striking W. to WNW, are shown on seismic sections of lines 32E and 33E, situated W. of Anholt (Plate 2, figs. 1 and 2).

An increase in the combined thickness of Lower Cretaceous and Jurassic formations also occurs $\mathrm{S}$. of Anholt, where these formations are steeply inclined towards the N.E. At Anholt situated at the downthrown side of a basement "high" a reduced Triassic section is probably only regionally covered by thin Jurassic and Lower Cretaceous.

This feature of thickening may be partly explained as the result of a major period of uplift of Fennoscandia relative to the Danish Embayment, which occurred during the transition from Jurassic to Cretaceous times. The marginal zone between the areas of uplift and subsidence seems to have functioned as a basin during the main period of the Jurassic while thick deltaic and marine sedimentation was a result of the structural development.

Displacements accompanying this period of uplift reached a main faulting activity within the rather narrow marginal zone of S. W. Sweden.

Steeply inclined Post-Triassic strata S. of the island of Anholt and East of it suggest the presence of a Jurassic sill which centre stretches approximately SSW from Anholt towards NW and E, separating the Kattegat area into partially open basins of Cretaceous deposition. These depositional areas may be formed by the NW. part of the Kattegat area and, in the E. part, by the N.W. extension of a large part of the marginal zone in Scania.

As mentioned, the structural development within Cretaceous time could only be estimated by means of the reflector at the Base of Upper Cretaceous chalk and limestone. The Cretaceous formations in the Kattegat area have been strongly affected by the largest NW-trending displacements which locally are nearly vertical. A main period of activity along these faults is probably related to the Late Kimmerian orogeny.

South of the WNW-ESE trending fault which extends from the North of Djursland towards the North of Sjælland and into a large fault between Helsingør and Helsingborg, the Upper Cretaceous chalk and limestone is locally more than $2.2 \mathrm{~km}$ (or $1.400 \mathrm{secs}$.) thick.

North of this fault the Upper Cretaceous section crops out and is strongly affected by structural deformations. NW. of Sjælland and in the Øresund area, where Pre-Quaternary outcrops have locally been marked on the map, this fault forms a sharp boundary with the thick sedimentation in North Sjælland, where 1849 m of Upper Cretaceous formations were drilled. Obviously a major displacement occurred along this fault during the sedimentation of the Upper Cretaceous.

Tectonic movements between Jurassic Kimmeridge and Cretaceous Campanian have been reported by professor Gunnar Larsen et al. near a flexure 
which was encountered in drillings between Helsingør and Helsingborg in 1965. According to professor Larsen, somewhat deformed Upper Cretaceous deposits near this flexure also indicate later movements.

A large displacement of the horizon at the Base of Upper Cretaceous is also found along the NW-SE trending normal fault which increases regionally from the Limfjorden towards the south of Anholt. A structural relationship on both sides of this fault suggests a main period of uplift during late Upper Cretaceous or more recent times. It may be associated with the Vraa-fault in North Jylland which borders the Rønnebjerg-graben.

Subsurface control in N. Jylland indicates this fault to be of Post Cretaceous age.

A mantle of Pleistocene glacial drift of varying thickness covers the Kattegat area, though regionally inliers of Upper Cretaceous chalk and limestone may be present (for example the Pleistocene reaches more than $229 \mathrm{~m}$ at Anholt, more than $171 \mathrm{~m}$ at Læøø and $291 \mathrm{~m}$ in Vendsyssel). The rocks immediately underlying this cover vary locally in Djursland and N. Jylland from Tertiary through Upper Cretaceous.

Conclusion. In general it appears that the tectonically disturbed belt of the Border Zone fades away towards the N.W. portion of the Kattegat.

In the central part of the Kattegat, more deep-seated, basement related fault blocks are situated within the northern margin of the Danish Embayment.

Mesozoic sediments form a N. E. trending flexure in a marginal trough E. of Anholt, which marks the trend of a Jurassic sill.

The combined effect of long-lasting tectonic movements, which took place from Pre-Jurassic through late Cretaceous or early Tertiary time is regionally recognized.

The largest W. to NW-trending displacements are possibly the result of wrench faulting due to compressive stresses towards the inflexible portion of the basement. It is, however, difficult to determine anything apart from their strike, the point of near vertical dip and the fact that the throw along these faults varies greatly.

The location of the island of Anholt indicates a mainly tectonic development of this area.

A large part of the area enclosed by W. to N.W.-trending fault zones in the W. portion of the Kattegat forms a zone of uplift within the boundaries of the depositional areas, which may have been shaped mainly during late Cretaceous or more recent time. 


\section{S. Øresund and W. Østersø}

\section{Geophysics}

The marine reflection seismic work in the S. Øresund and W. Østersøen was carried out on behalf of Gulf Oil Company of Denmark Ltd. over various periods.

In 1964 Western Geophysical Co. started a marine reflection program including the traverses marked 22E to 29E (Plates 3 and 4) which cover $405 \mathrm{~km}$ in the area. A recording technique was used to obtain 2- and 4-fold composite sections, featuring a frequency variant filter with a high cut of only $35 \mathrm{~Hz}$ and automatic volume control. Velocity analyses based on NMO estimates were printed at regular intervals along these sections. The quality of these 4-fold data was good in the northern portion of the area.

During 1969 Prakla Seismos Gmbh. completed a shallow water reflection survey, whose lines were numbered $45 \mathrm{E}-55 \mathrm{E}$ and cover about $410 \mathrm{~km}$ in the area. A technique of multiple coverage shooting was used in order to obtain 12 -fold seismic sections. For this purpose a $1600 \mathrm{~m}$ long hydrophone array was chosen with 24 hydrophone groups, spaced at $50 \mathrm{~m}$ intervals and 32 detectors per group. The digital recording featured a filter ranging from $14-92 \mathrm{~Hz}$ and ganged automatic gain control. The recordings were further processed, utilizing deconvolution before stacking and a frequency variant filter range of $10-60 \mathrm{~Hz}$. Results of processed velocity analyses were displayed in computer derived R.M.S., and interval velocity plots.

These 12-fold reflection data were superior to the previous survey, especially in the S. portion of the Øresund area.

In order to provide ties with the subsurface control in the Ørslev No. 1 well (Falster) and the Slagelse No. 1 well (S. Sjælland) much of the single fold landdata was used. These lines were shot during 1965 and 1966 by Seismograph Service Ltd.

\section{Reflecting horizons}

Four geological markers were identified in the Sjælland area. These marker horizons belong to the approx. Base of Upper Cretaceous chalk and limestone, the Top of Triassic (which corresponds to the Rhaetic formation, a marine and deltaic deposition in these areas), the Base of the Zechstein, and a PreZechstein formation probably situated near the basement. 
Due to lack of velocity information from wells in S. W. Sweden and to the fact that correlations of two of these horizons across large displacements in the Øresund become questionable in the 4-fold composite data, only the two most continuous of these horizons, namely the "Base of Upper Cretaceous" and the "Near Basement", have been mapped so far.

\section{Interpretation}

The approx. Base of Upper Cretaceous (Plate 3). The Base of the Upper Cretaceous chalk and limestone produces a strong event and is continuous throughout most of the area, except in regions with thick sand-deposits from the Pleistocene.

The Upper Cretaceous section thickens regionally from South to North and North East.

The chalk is thin or less than about $430 \mathrm{~m}$ (or .300 secs.) in the S.W. portion of the Østersøen and becomes more than about $1370 \mathrm{~m}$ (or .860 secs.) thick in the Øresund area.

In the central part of the map the horizon of the Base of Upper Cretaceous shows a flattening of the dip-rate towards the "basement" high of the island of Møn and the S.E. part.

Faulting or strong folding involving the Upper Cretaceous formation is limited to the Southern part of the Øresund and the area formed by the extension of the Fyn-Grindsted High in the S.W. part of the map.

In the first instance these deformations are related to a fault block complex of the Lower Palaeozoic section of which corrections extended locally into the Mesozoic.

In the S.W. portion of the area the N.W.-S.E. trending faults are associated with fault blocks of the Ringkøbing-Fyn-Falster High.

An eastward extension of the Permian Zechstein, which was penetrated in the Slagelse No. 1 well in S. Sjælland, could not be confirmed in the Øresund area, since no such sediments were found in wells or in outcrops in S. Sweden.

In Sjælland, seismic control indicates a probable thinning of the Permian section eastwards towards Scania and it therefore appears that if present in the Øresund this section may be thin.

A structural "high" on the island of Møn is outlined in a singlefold section of line M-1. It appears that the chalk lies within about $100 \mathrm{~m}$ of the Pre-Cambrian and reaches a thickness of less than $580 \mathrm{~m}$ (or . 380 secs.) in this area.

A Pre-Zechstein horizon (probably Near Basement) (Plate 4). The reflector of 
the Pre-Zechstein horizon is identified in the Slagelse No. 1 well as belonging to the approximate boundary between a hard Ordovician and Cambrian Shale sequence and a Lower Cambrian series of quartzitic sandstones. These sandstones are believed to be equivalent to the Balka quartzite on the island of Bornholm and the Hardeberga sandstone series of Scania.

In Scania the Hardeberga sandstone is regionally more than $95 \mathrm{~m}$ thick while on Bornholm $60 \mathrm{~m}$ of Balka quartzite is locally underlain by $100 \mathrm{~m}$ of Lower Cambrian Nexø sandstone, which rests directly upon the Pre-Cambrian basement.

According to the Slagelse No. 1 well, located close to the Ringkøbing-FynFalster High, the Lower Palaeozoic section is probably reduced in this area. It is therefore assumed that the seismic horizon near the Top of the Lower Cambrian sandstones reflects much of the trend of the underlying basement in the area of investigation.

In general this "near basement"-horizon produces a strong event in the northern and the south-western parts of the Østersø area. Towards S.E. this reflector becomes difficult to define in the 4-fold composite data.

The interpretation of the "near basement" horizon shows large N. to N.W.striking basement-related normal faults which appear to be associated with the tectonics of the Fennoscandian Border Zone. These faults border strongly tilted blocks of the Palaeozoic section. The throw along these faults varies much, being largest in the Øresund area. These variations probably arise either because heaved blocks border downthrown counterparts and vice versa or because some independent steep warping occurred.

The origin of the major $\mathrm{N}$ - og NW-striking structures is probably related to the Caledonian orogeny. Adjustments resulting from the largest displacements extended only locally into the Mesozoic by means of folding or faulting.

In the central part of the area a complicated E-W trending fault system may have acted as adjustment between the major faults.

A NW-SE trending fault block complex is found in the southern part of the area near the Fyn-Grindsted High. These displacements are of a smaller scale than in the Oresund area but affected the Mesozoic formations to a larger extent.

The basement horizon is about $700 \mathrm{~m}$ deep (or .480 secs.) where it reaches its highest elevation on a section of line M-1 on the island of Møn. This section 
also shows that the basement "high" at Møn was an important feature into the Cretaceous time.

From the Møn "high", which is shielded on its N.E. side by a large basementfault, the "near basement" horizon dips regionally towards the N.E. across large fault blocks into the Øresund.

A depth of about $4500 \mathrm{~m}$ is found on a section of line $47 \mathrm{E}$ at the downthrown side of the largest displacement, which has a throw of about $2800 \mathrm{~m}$. This is shown in a section of this line in fig. 1.

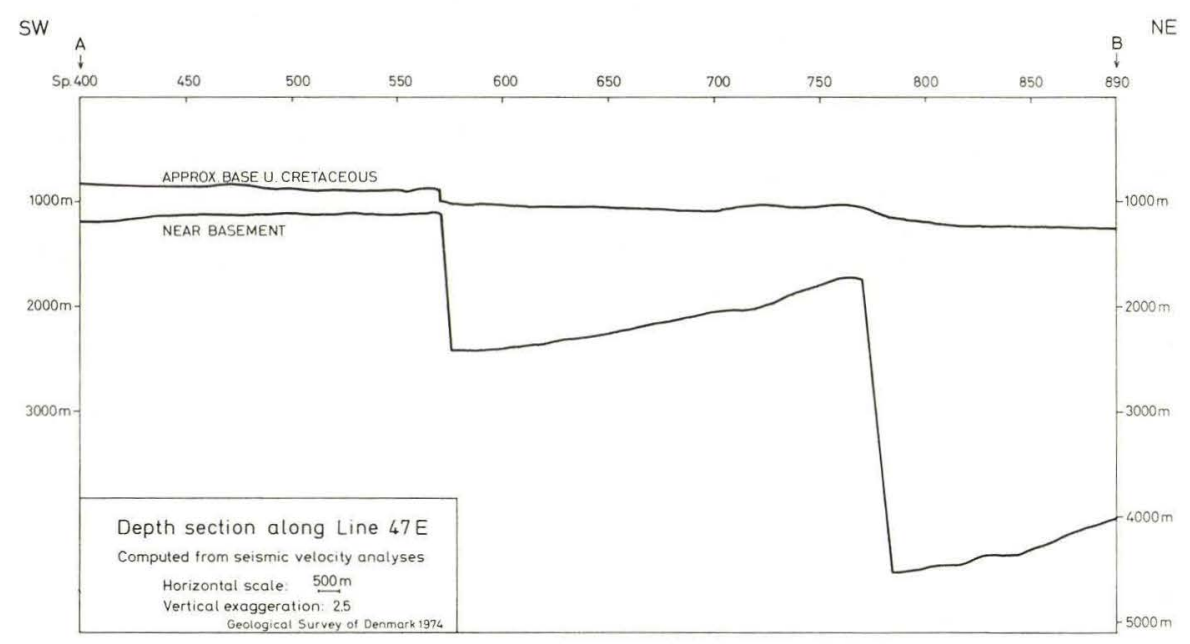

Text-fig. 1. Depth section A-B along line 47E as shown in Plates 3 and 4.

According to this section and newly-published information from wells in S.W. Sweden it appears that the Lower Palaeozoic section thickens in the area between Sjælland and Scania.

At the S. side of the Fyn-Grindsted High the "near basement" horizon dips regionally into the North German Salt Basin.

Additional seismic coverage would be needed to outline "near basement" structures in the E. and S.E. of the area. 


\section{Geological outlines of the Fennoscandian Border Zone}

Ole Bruun Christensen

\section{General geological outline of the area}

The Fennoscandian Border Zone appears as a structural unit between the Fennoscandian Shield and various basin structures in a North Sea depression west and southwest of the Fennoscandian Shield. The Fennoscandian Border Zone has been discussed as a structural unit for many years. However, the total extent, the lateral limits, and the development of the region have not yet been satisfactorily explained, but many research projects on these problems are in progress.

The Fennoscandian Border Zone has been reviewed under the name Tornquist-line (Jentzsch 1888, Tornquist 1908 and 1910, Bergström et al. 1973 a.o.) and mapped as a structural lineament from Danmark, through Skåne (Scania) in Sweden, into Pomerania in Poland towards the Carpathian range. This lineament seems in newer Polish and German literature to be called TornquistJentzsch Line (or Tornquist-Teisscyre Line), probably owing to remarks by Franke (1967 p. 138). This lineament is more or less parallel to a number of fracture zones crossing the basement through the Southern Baltic Sea (Golub \& Sidorov 1971) and parallel to many fractures in the North Sea area.

Since the first detailed structural subdivision of subsurface units in Danmark (Becksmann 1931 and 1933, Ødum 1935) many newer details have provoked many other subdivisions. Becksmann subdivided southern Danmark in four or five blocks (Schollen) based mostly on magnetic interpretations (the Fennoscandian-Baltic Block, the Adler Block, the Cimbrian-Obotritian Block etc.).

Sorgenfrei subdivided Danmark in four structural regions (Sorgenfrei \& Buch 1964, Sorgenfrei 1966):

1) The Fennoscandian Border Zone

2) The Danish Embayment

3) The Ringkøbing-Fyn High

4) The North German Sedimentary Basin

and all of them seem to be bounded through Danmark by NW-SE trending fault zones.

The Fennoscandian Border Zone is a large structure in the geological framework of Northern Europe. It is a boundary zone between two different geological regions: a structurally relatively high region northeast of the Fenno- 
scandian Border Zone (the Fennoscandian Shield or the Fennoscandian-Baltic Shield) and a structurally relatively low southwestern region (the North Sea basins).

The Fennoscandian Border Zone is bordered by faults and flexures. Such features are difficult to recognize on the Fennoscandian Shield, where younger deposits are very scarce, and in the basins of the North Sea area, where such features are often buried below a thick sediment cover. Along the Fennoscandian Border Zone there are exposures in Skåne and on Bornholm where these tectonic activities have been studied with respect to form, scale, and age.

The Danish Embayment is an elongated structure with a thick sequence of Triassic and locally thick Jurassic deposits between the Fennoscandian Shield and a relatively high area called the Ringkøbing-Fyn High. Both highs are characterized by thin Triassic and Jurassic deposits (Sorgenfrei 1966). The Danish Embayment continues from northern Jylland towards the northwest into other basins in the northern part of the North Sea. This northwestern

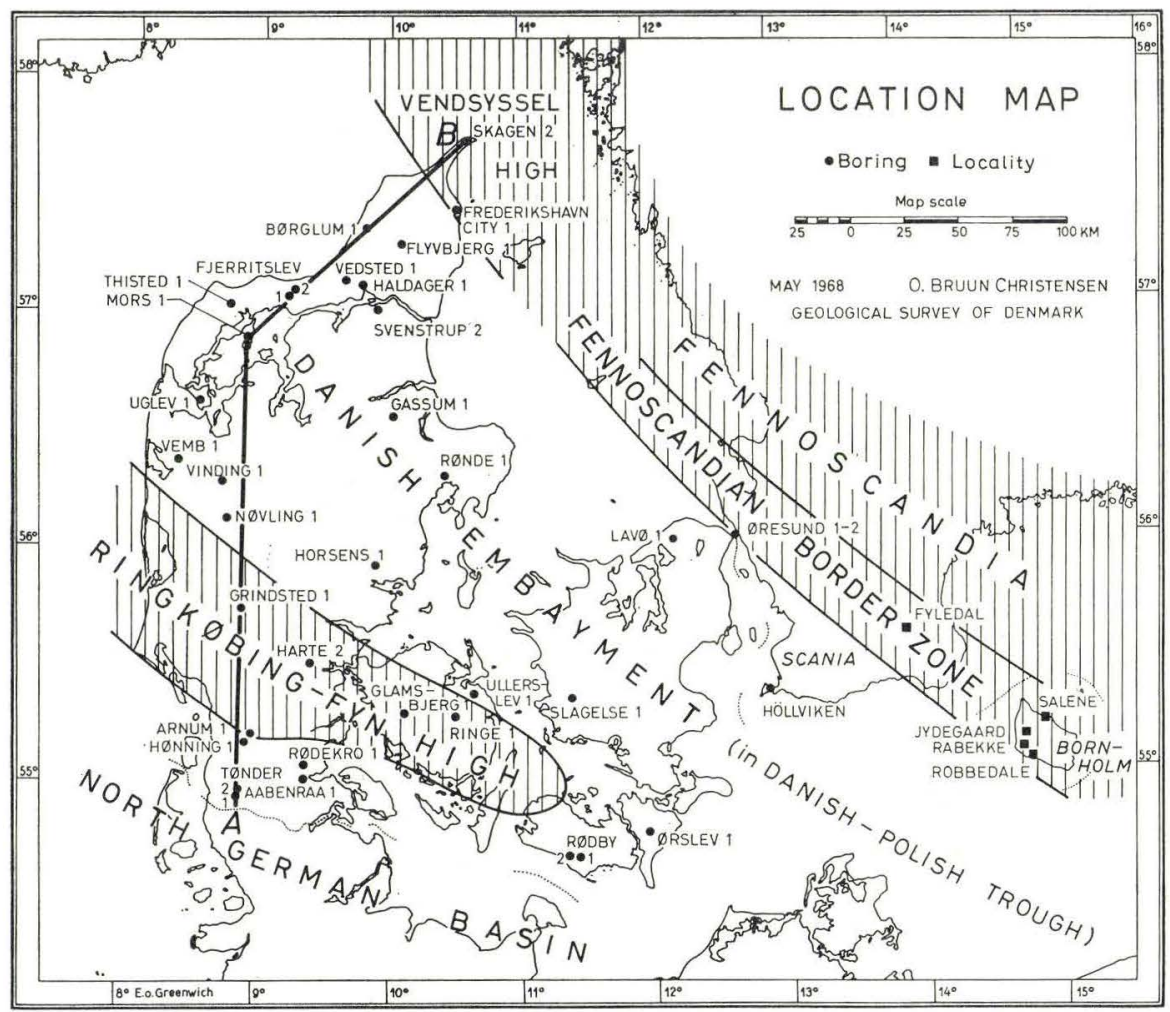

Text-fig. 2. Locations and main structural regions in Danmark. A section from south to north (A-B) showing simplified important structures has been outlined in text-fig. 3. 

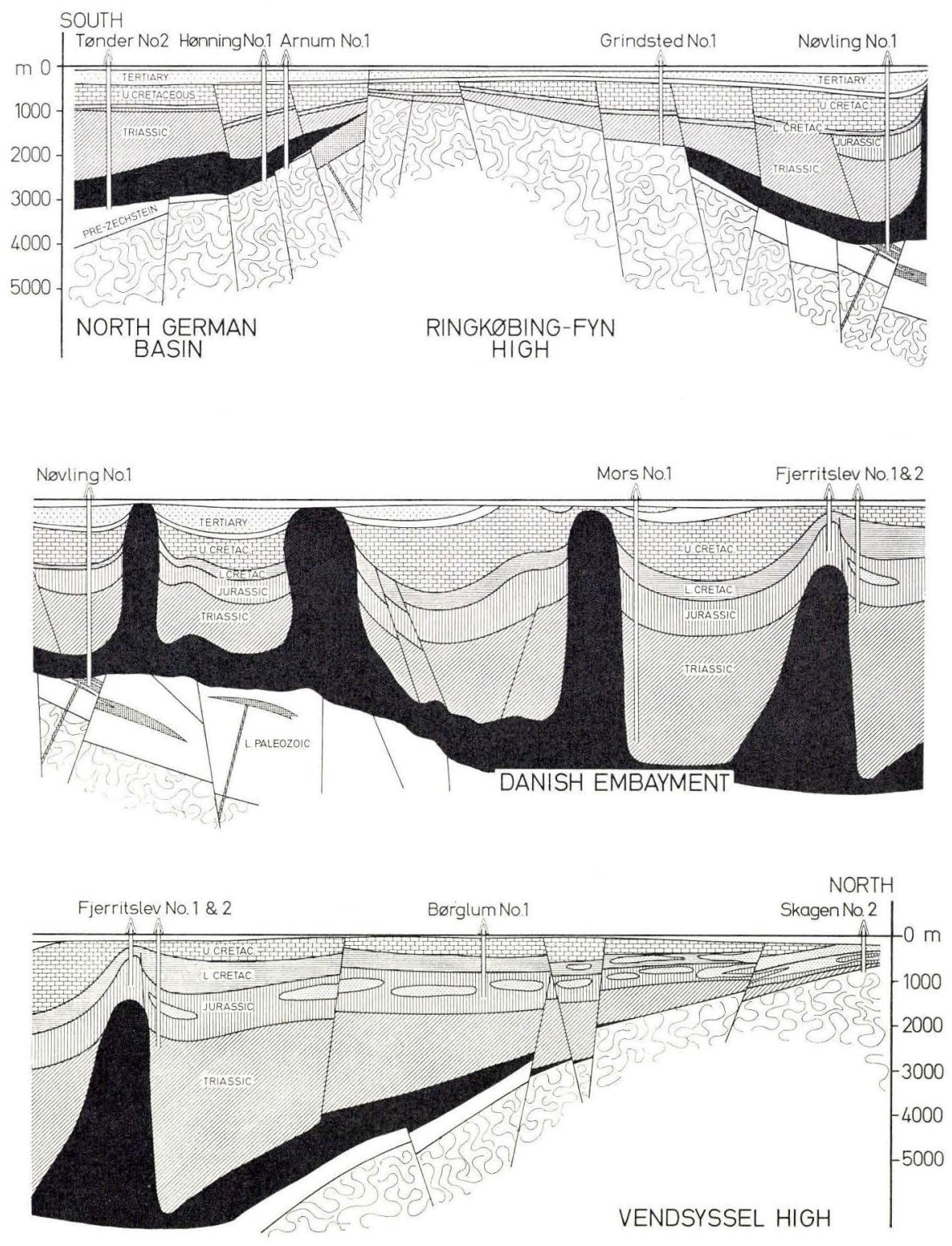

O Bruun Christensen

Geological Survey of Denmark 1974

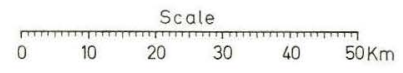

Text-fig. 3. Hypothetical section through Jylland from south to north (cf. text-fig. 2) showing some simplified important structures. 
part of the Danish Embayment is characterized by local structures caused by Zechstein salt movements (cf. Sorgenfrei 1969, Banke Rasmussen 1974). In the southeastern part of the Danish Embayment, complicated block structures in Sjælland and in Skåne seem to indicate a disappearance of the basin characteristics, but the thickness and nature of the deposits in the area indicate a continuation of the basin during some time intervals towards the southeast into DDR and Poland. Local structures caused by moving Zechstein salt are not common in the area. This part of the Danish Embayment has been named the Adler Block (Adler-Scholle) by Becksmann, and is considered to continue in the Marginal Synclinorium in Poland (Pozarysky 1966). Here it is partly connected to the Baltic Basin (Sorgenfrei 1969), or the Peribaltic Syneclise (Dadles 1974), or Baltic Syneclise (Golut \& Siderov 1971). Mostly because of the thickness of the sediments in the whole Polish-Danish Trough, this structure has also been classified as a geosyncline (Haug 1921, Brotzen 1945 a.o.) or, connected to a craton, a geosynclise.

The Ringkøbing-Fyn High is a relatively high Precambrian area below Fyn and Jylland, without Jurassic sediments. It continues in a northwestern and western direction below the eastern North Sea. It is cut by NW-SE trending fault zones giving the blocks in the Ringkøbing-Fyn High an "en échelon" outline (Sorgenfrei 1966) possibly indicating wrench-faulting in the area (Baartman 1973). The Ringkøbing-Fyn High also continues in a southeastern direction from Fyn below Falster and Møn. The Cimbrian-Obotritian Block (CimbrischObotritische Scholle) seems to be more or less synonymous with the Ringkøbing-Fyn High. Along the southern margin of the Ringkøbing-Fyn High, Permian volcanites have been located (Sorgenfrei \& Buch 1964).

The North German Sedimentary Basin in Danmark is the northern marginal part of the northwest German depression area, ranging from north of the Danish-German boundary to the island of Lolland. Here the Zechstein salt is thick and forms local structures, mostly as NNE-SSW trending salt-walls.

A structural section north-south through Danmark (text-figs. 2 and 3) indicates a high basement in the blocks of the Ringkøbing-Fyn High and in the Vendsyssel High. In the deepest part of the Danish Embayment the basement is covered by more than 5000 metres of sediments. $8.3 \mathrm{~km}$ has been observed by refraction profile (Carsten \& Hirschleber 1969). A seismic refraction profile (Hirschleber, Hjelme \& Sellevoll 1966) north-south through Jylland rather similar to the outline in text-figs. 2 and 3 indicates the depth of a basement with a slight high in the central part of the Danish Embayment. The high of this "seismic" basement may be interpreted as corresponding to a high among basaltic rocks partly included as volcanites in old Paleozoic deposits distributed in central Jylland. A strong gravity anomaly probably indicates this region (Bruun Christensen 1973). 
In the Danish Embayment the thickness of the crust has been observed to be between 29 and $33 \mathrm{~km}$ (Carsten \& Hirschleber 1969). North of the Fennoscandian Border Zone the crust is thin near the Oslo Graben, and below the northern North Sea in the Caledonian area between Norway and Scotland. Depths of about $38-40 \mathrm{~km}$ for the Mohorovičič-discontinuity have been observed in the central part of Norway below the Caledonides and in the Baltic area far from the Oslo Graben.

The frequency of some observed earthquakes (e.g. Tamrazyan 1969) seems to be larger in the old consolidated areas with thin crust than to the south in the basins which also have a thin crust, but a thick cover of sediments.

The Fennoscandian Border Zone has been structurally determined using traditional tectonic strike-directions or trends for central Europe. Various trends have been used separately or by impaction for the tectonic history for the area. Generally it seems evident that the number of important tectonic strike-directions increases northwards through Danmark (Ødum 1935). The faulting takes three traditional directions or trends. The Rhenian trend $\left(25-30^{\circ}\right)$ includes many Precambrian and Paleozoic structures e.g. the "MittelmeerMjösen Zone" of Stille (1925-1928). The Hercynian trend (ca. 120 ) includes the majority of the directions of Paleozoic dikes in Skåne. The Dinaric trend (ca. $140^{\circ}$ ) is the direction of the Tornquist-Jentzsch Line (Lindström 1967). In southern Sweden these structures have been studied intensively. There, the Fennoscandian Border Zone is composed of small horsts and grabens in the landscape surrounded by sediments, and the area is well mapped (Regnéll 1967 a.o.).

\section{Some structures related to the Vendsyssel High}

Our knowledge of the Fennoscandian Border Zone in the Skagerrak is relatively limited. From magnetic measurements (cf. Holtedahl \& Sellevoll 1971) it seems to continue from Vendsyssel towards the Norwegian coast.

Demonstration of volcanic activities at least during the Permian and Tertiary (Noe-Nygaard 1967, Sharma 1970, Åm 1973, Flodén 1973 a.o.) indicates that tectonic activities have influenced the deposits in the area. The great difference in subsidence for the area also indicates the possibility of strong tectonic activities. In the North Sea not far from the Norwegian coast the subsidence during the Tertiary was more than $3000 \mathrm{~m}$ while the Norwegian mainland rose $2000 \mathrm{~m}$ (Torske 1972). Lamprophyric dikes of Jurassic age have been found parallel to the coast south of Bergen in southwest Norway (cf. Holtedahl \& Sellevoll 1971), and Jurassic volcanic activities have also been reported from the central part of the northern North Sea (Howitt 1974). 
The Vendsyssel High below northernmost Jylland seems to have some structural connections in common with the Fennoscandian Shield. Borings around Skagen and Frederikshavn indicate a thin Permian or Triassic cover of clastic sediments on the gneissic basement rather similar to rocks in the Fennoscandian Shield (Noe-Nygaard 1963). The Jurassic and Lower Cretaceous sediments include some marine beds, and the Upper Cretaceous is outcropping between Frederikshavn and Skagen. The Quaternary is often 150-200 metres thick in the northern half of Vendsyssel where it seems to rest on a rather smooth surface of Upper Cretaceous. In the southern and southwestern part of Vendsyssel many outcrops of Upper Cretaceous Chalk have been mapped. Here the Permian seems to be present as Zechstein evaporites. Among many nearly parallel faults, the Vrå Fault limiting the Rønnebjerg Graben is important for the area.

Examination of the bedrock in the eastern Skagerrak (Flodén 1973) justified an older opinion (Lind 1967, Sorgenfrei 1969) that the Precambrian Bohus Granite, intruding in the gneiss along the Swedish coast, has a southwestern direction towards the Vendsyssel High. In this eastern part of the Skagerrak no sediments older than Triassic seem to overlay the gneiss, the Bohus Granite and the Permian volcanic rocks.

NNE-SSW fracture systems (Koster and Sote Fjord Fracture Systems) between east-west dipping blocks have been mapped in the gneiss area. This area between the Bohus Granite and the Hvaler Deep Fracture Systems are faulted into the Oslo Graben. The faults continue into an area with Mesozoic sediments. No Upper Cretaceous sediments have been found in this part of the Kattegat area. The Lower Cretaceous in the area consists of the limnic Skagen Formation (Larsen 1966). The name Skagen Formation has unfortunately been used by Flodén for Pleistocene deposits. As the name has furthermore been used for other deposits e.g. also in Västergötland (Bergström \& Nilsson 1974), its use by Flodén in the Skagerrak area must be considered as confusing.

\section{Structures in the northern Kattegat area}

A huge uplifted zone up to 50 kilometres broad crosses the Kattegat area in a NW-SE direction from the Limfjord to the Øresund (The Sound). Alternating axis-depressions and axis-culminations in NW-SE directions are rather similar to the Ridge of Helsingborg-Romele Horsts in Skåne (Lundegårdh, Lundquist \& Lindström 1964).

The seismic investigations in the Kattegat have been interpreted and discussed by Baartman (pp. 12-16 in this paper) and a horizon at the base of the Upper Cretaceous is mapped on plate 1 by Baartman. Older tectonic structures 
below the Upper Cretaceous deposits and covered by these are naturally not illustrated in plate 1 . Some lineaments of structural importance have also been included on plate 1 of Baartman (e.g. the limit of the Zechstein salt basin through the Kattegat area).

North of the uplifted structure through the Kattegat no Zechstein has been located, the Triassic thins out, and the Jurassic and Lower Cretaceous locally become thicker. The Upper Cretaceous in particular is folded and in many places eroded away. No Tertiary has been found. The tectonic activities occur in the Triassic (Early Kimmerian), but during Upper Jurassic to Lower Cretaceous the area has been activated mostly by tension forces (Late Kimmerian). Later in Cretaceous and perhaps in Lower Tertiary time mainly compression forces from SW to S affected the area. The tectonics are rather similar to those in Skåne recently analysed by Bölau $(1969,1972,1973)$. Here antithetic movement of fault blocks, reverse drag and transverse tectonics have been pointed out as the tectonic style (Bölau 1969, 1972). Old Kimmerian tectonics activated epeirogenic forces. During the Jurassic and especially in the Upper Jurassic, however, orogenic disturbances in connection with successive displacements of fault blocks probably produced many of the present structures in Skåne (Bölau 1973).

Also as in Skåne the Dinaric and the Hercynian trends are the most common. Many faults in Skåne show the horizontal striations of wrench faults (Lindström 1967). A difference in the direction of the fault zone in Skåne can be observed in some of the first produced maps (e.g. Nathorst 1894). By remote sensing by satellite pictures it has also been observed that the NW-SE trending fault lines in the western part of Skåne (e.g. the horsts of Kullen and Hallands Ås) have a more E-W orientation than in eastern Skåne (Behrens 1973). The $\mathrm{N}-\mathrm{S}$ direction probably indicates that the central schistosity zone in the gneiss also turns smoothly to more NNE-SSW directions in southern Skåne. Large lineaments with other directions have also been observed by remote sensing in Skåne (Lidmor-Bergström 1973).

The deeper N-S trended structures below the sediments in the Kattegat seem to have been reactivated by movements at least in Cretaceous time or later. One of the most pronounced NNE-SSW striking faults east of the tilted Anholt structure seems to have some connection with a thrust line in western Sweden between the Gothian and Pre-Gothian regions where movements have occurred since Late Gothian time. In central Skåne the eastern boundary to the Gothian rocks also forms a local area with small graben structures and with Late Mesozoic volcanos.

Other old north-south structural directions can be observed indirectly on aeromagnetic maps as small systems of anomalies around the island of Læsø.

The Kattegat area east of the NNE-SSW trending faulted flexure between 
Anholt and Store Middelgrund seems tectonically to have been a more stabile area since Cretaceous time. It is locally covered by thin Upper Cretaceous beds (Bergström et al. 1973) and near the Swedish coast Paleozoic and Lower Mesozoic deposits form the cover.

\section{Structural outlines from the southern Kattegat to the western Baltic Sea}

These areas belong to the Danish Embayment, in Skåne named the MalmøYstad Embayment (Lundegårdh, Lundquist \& Lindstrøm 1964). In the southern Kattegat the sediments dip rather strongly to the southwest towards the uplifted area near the Ringkøbing-Fyn High. The basement is faulted in a direction from N-S to NW-SE. The Zechstein is rather deep seated, but no important salt structures seem to occur. The Triassic and the Cretaceous deposits are very thick, while the Jurassic section is thin, at least in the southern central Kattegat area.

The development of the Fennoscandian Border Zone is reflected in the Mesozoic and Caenozoic sediments in the surrounding basins. Descriptions of these basins in Danmark are given in detail in other papers, e.g. Sorgenfrei \& Buch 1964, Larsen 1966, Sorgenfrei 1969a and b, and Banke Rasmussen 1972.

The development along the Fennoscandian Border Zone during the Paleozoic can be demonstrated in Skåne and on Bornholm. Deposits from Lower Paleozoic occur northeast of the Fennoscandian Border Zone from the Oslo Graben, through southwestern Sweden in Skåne and Bornholm. Lower Paleozoic deposits have been found in deep borings in the Danish Embayment (Bruun Christensen 1971 b, Chr. Poulsen 1974).

In the southwestern Baltic Basin (Balto-Scandian Basin according to Chr. Poulsen 1974) a thick Paleozoic sequence has been recognized. In the area between the Møn High and Skåne a very thick sequence of Lower Paleozoic seems to be present. Most probably it includes about 2000 metres of Silurian sediments like those in Pomerania. A thick Paleozoic sequence may also be present below northeastern Sjælland. In western Sjælland and in Rügen respectively the Silurian is reduced or absent. In Rügen the Ordovician is probably 1500 metres thick (Franke 1967) but it is more or less reduced on Sjælland (borehole Slagelse No. 1). There is no doubt that the area has been tectonically affected during Lower Paleozoic time in connection with the Caledonian orogeny, but strong tectonics have also affected the whole area at least in the Lower Permian. Paleozoic volcanites in the Danish Embayment - also those 
from Upper Silurian - have all been determined as carrying Permian ages (Larsen 1972). The Upper Paleozoic series is most important for a structural evaluation of the Fennoscandian Border Zone in Danmark, though some of the structural trends (Hercynian and Rhenian) seem to be older than the Variscan orogeny. It seems to have affected parts of northwestern Europe. In two intervals, namely during Upper Carboniferous or Lower Permian, dikes were intruded in the deposits along the already existing NW-SE trends in Skåne. Their ages have been determined by paleomagnetic methods (Mulder 1971, Bylund 1974) and no tectonic rotation has been discovered. Broad dikes of nearly the same ages from the Oslo Graben intruded the basement in N-S directions along the northern part of the Swedish west coast (Samuelsson 1971). Thick sills of Upper Carboniferous age occur in Västergötland (Mulder 1971). It is characteristic for the Paleozoic and for the basement in the western Baltic Sea between the Ringkøbing-Fyn High and Skåne that it has been strongly tilted in horst and graben structures dipping in southwestern directions. On the southern flank of the WNW-ESE striking tilted block, the northern margin of which is situated immediately north of Møn and Rügen (Møn-Arkona Block), the Carboniferous and the Permian are thinning northwards (cf. Bruun Christensen 1971 a, fig. 1). In Skåne, folds with a NW-SE-axis, weakly overthrusted (Lundegårdh, Lundquist \& Lindström 1964) and with tilting of the basement, have been developed after the intrusion of the Upper Paleozoic dikes. South of the Møn-Arkona Block a belt with Upper Carboniferous and Lower Permian volcanites continues WNW out into the eastern North Sea area.

The distribution of the Zechstein deposits gives the best outline of the basinal structures formed in the area south of the Fennoscandian Border Zone after the Variscan orogeny. Here the Zechstein deposits, mostly evaporites, have probably been laid down on a surface which in some areas is partly levelled by Lower Permian (Rotliegendes) sediments. In the Danish Embayment the Zechstein has been deposited in areas from northern Jylland across the western Kattegat to western Sjælland. In the North German Basin the Zechstein deposits occur nearly E-W south of the Ringkøbing-Fyn High. Zechstein has not been found north of the Fennoscandian Border Zone and Zechstein deposits have not been recognized by means of the seismic investigations in Danish areas east of Sjælland and Møn.

The faulted flexure towards the uplifted diagonal Kattegat structure was renewed during the Cretaceous, and probably continues into the HelsingørHelsingborg flexure (Larsen et al. 1968). Some lower Upper Cretaceous deposits (Campanian-Santonian) are folded and dextrally transformed structures have been observed. The Upper Cretaceous rests disconformably on Upper Jurassic. Between Cretaceous and Tertiary time the area has probably been elevated.

This regional zone formed the most central part of the basin during Jurassic 
time. In the western Kattegat area the thickness also seems to increase northwards from this zone.

Heavy-mineral analyses of the sediments of Middle Mesozoic age only have indicated weak relationships to the Precambrian of the Fennoscandian Shield, whereas the sediments from the middle of Upper Cretaceous time (CampanianSantonian) seem to include reworked Jurassic material (Larsen 1966). The large faulted flexure dipping nearly $45^{\circ} \mathrm{SW}$ along the Øresund and into Skåne has been developed at that time and the Uppermost Cretaceous is not included in the flexure. It is difficult to recognize a continuation of the complicated flexure in a southeastern direction through Skanne. Southwest of the ridge of the Helsingborg-Romele Horst the Mesozoic beds dip 1000-3000 metres into the Malmø-Ystad Embayment (Lundegårdh, Lundquist \& Lindstrøm 1964). Northeast of the Romele Horst in the northern part of Vombs Trough a 600 metres thick series of marl of Lower Upper Cretaceous age rests nearly horizontally on steep Jurassic beds. In other localities in the Vombs Trough corresponding Cretaceous beds have been tilted along a northern fault zone.

In northeastern Sjælland a system of fault zones has been mapped, mostly on the basis of dislocations of Upper Cretaceous and Tertiary deposits, and is of Lower Tertiary age or even younger (Rosenkrantz 1931). Close to, and almost parallel with, the Helsingør-Helsingborg Flexure (cf. Larsen et al. 1968) the Alnarp Graben structure crosses northwestern Sjælland, the Oresund and southwestern Skåne. It is an erosion feature bordered by faults, the southwestern of which is the most marked (Sorgenfrei 1945, Rosenkrantz 1937 a.o.).

Among the fault zones of eastern Sjælland, the so-called Carlsberg fault crossing the city of Copenhagen towards the south of Amager on the eastern side of the fault zone has been displaced vertically by about one hundred metres. This fault is rather conformable to the southern Alnarp-fault. All over the eastern part of Sjælland and in the southwestern part of Skåne, structures indicating faulting and folding of the oldest Tertiary have been observed (cf. Rosenkrantz 1937, 1942, Wegner 1966, Ødum 1971 a.o.), placed more or less fan-shaped around southwestern Skåne (Hansen 1941, 1943, Brotzen 1940).

\section{Anholt}

The island of Anholt in the central part of the Kattegat is perhaps closely connected with the northwestern part of the Kattegat including the Vendsyssel High. The whole area around the island is characteristic in having no Zechstein, in belonging to a basin with increasing thickness of Jurassic and Lower Cretaceous sediments towards NNW, in having the Triassic lying more or less directly on the basement, and in being an area covered by relatively thick 
Quaternary, consisting mostly of marine sediments. The structures have been activated by strong compression from the southwest or west. The Jurassic and Lower Cretaceous deposits locally seem to be thin on the Anholt structure and are probably directly overlain by Quaternary.

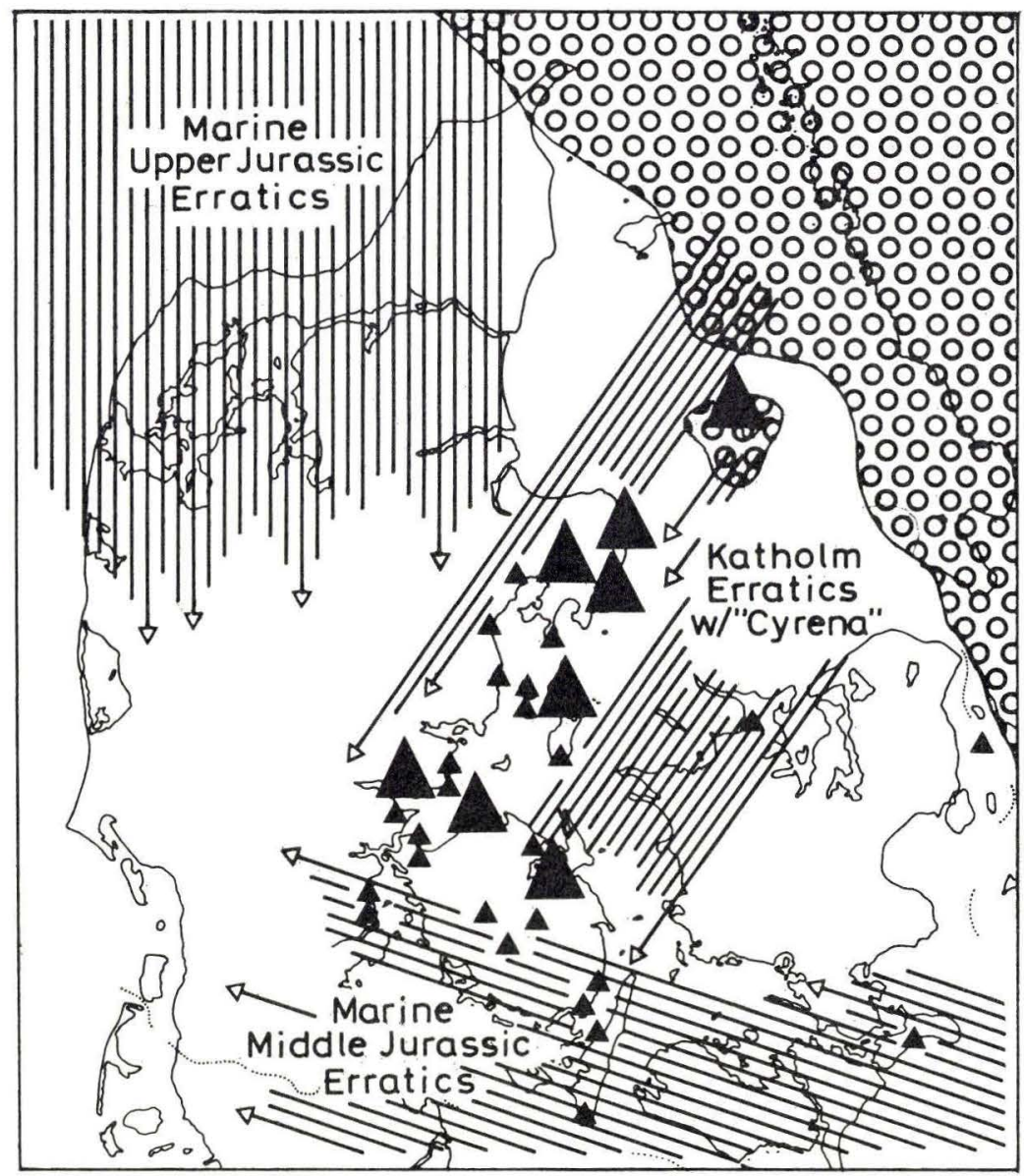

Text-fig. 4. An outline showing the three main directions of boulder trains in Danmark (hatched with arrows). They include local and exotic erratics. For each boulder train direction a more or less local fossiliferous erratic type is mentioned. The marine Middle Jurassic erratics may be exotic and originate from the southern Baltic Sea area. From the same area this boulder train carries some "Cyrena" erratics besides Katholm erratics indicated as dispersed finds. The finds of "Cyrena" erratics are noted by black triangles. Large triangles indicate large assemblages of erratics. Circles indicate areas with Pre-Upper Cretaceous below Quaternary. The statement of the material is based on the collections of erratics at the Mineralogical Museum of Copenhagen and the Geological Survey of Denmark, and on the literature. 
No borehole has hitherto penetrated the Quaternary in the Kattegat or on the islands of Læsø and Anholt. Nearly all the information about the deposits originates from geophysical interpretations and from borings relatively far away in Jylland or in Sjælland, in areas having little in common with the central Kattegat. Some information obtained directly from the deposits in the Anholt structure or from areas close to the structure is available, however.

In text-fig. 4, local erratics from hypothetical Middle Mesozoic exposures have been outlined as three main directions of boulder trains.

From the north of the Kattegat area, glaciers have transported exotic Norwegian erratics and fossiliferous marine Upper Jurassic erratics to the Danish mainland. From the northeast, glaciers have carried exotic erratics from Dalarne and Aland together with "Cyrena" erratics of local origin from an area near Anholt in the Kattegat. From the east and southeast, glaciers have transferred East Scandinavian erratics to southern Danmark. Among the sedimentary erratics marine Middle Jurassic and probably "Cyrena" erratics are included.

The "Cyrena" erratics have been known from North Germany since the middle of the last century, where Beyrich with some uncertainty referred them to Wealdian (Grönwald 1904). Their stratigraphical position has always been uncertain, at least in Danmark. Gottsche (1883) gave information of three erratics from Kalø, Katholm and Grenå respectively in central Danmark and determined the molluses in the blocks to be of Lower Oligocene age. Some geologists continued to classify them to Wealdian (e.g. Lundgren 1891), but others interpreted them as Lower Jurassic or Rhaetic (e.g. Stolley 1897 and Grönwall 1904).

The places of origin of the "Cyrena" erratics have been discussed for many years. Before the turn of the last century the southern Baltic area was usually pointed out as such a place, since similar deposits are exposed on Bornholm and in Skåne. Some of the material found in southern Danmark, northern Germany, and in Poland originates from southern Baltic areas. The strong concentration of block material containing "Cyrena" in central Danmark (textfig. 4) implies the existence of other places of origin. The southern Kattegat area was pointed out by Poul Harder as a hypothetical but natural place of origin for the "Cyrena" erratics of central Danmark (Grönwall 1904). This opinion was gradually accepted for the majority of the "Cyrena" erratics, which in this paper have been named "Katholm erratics".

The Katholm erratics contain macrofossils mostly classified as "Cyrena" and "Paludina". Some also contain fish remains or plant remains.

Some of the Katholm erratics contain microfossils. Most of these have been observed directly in the sediment under a microscope. Washing seems to destroy the microfossils. The microfossils consist mostly of inderterminable 
species of Cypridea, Fabanella boloniensis (Jones), Damonella sp., and Klieana $\mathrm{sp.}$

The material examined by Gottsche (1883) from Djursland and classified as Lower Oligocene does not seem to contain microfossils, but apart from this is similar to other Katholm erratics.

Molluscs and fish remains in material from Djursland in Central Jylland have been classified as Mesozoic (personal communications from professors Spjeldnæs and Strauch).

In the Katholm erratics from Anholt and from other places in Central Danmark, impressions of Cypridea are very common, and there is no doubt that all the Katholm erratics originate from Purbeckian-Wealdian sediments. The above mentioned ostracod species and some species similar to ones known from the South Baltic area seem to indicate that the erratics are of Purbeckian age.

Upon examination of the material labelled as "Cyrena"-material among erratics collected by the Geological Survey of Denmark, so many finds occur on the island of Anholt in the Kattegat that the place of origin of the Katholm erratics most probably seems to be in the neighbourhood of this island. Katholm erratics have been collected in many places and at many times along the shores.

Assumptions of occurrences of Tertiary deposits on the sea-bed around Anholt (Jessen 1897), as an explanation for the large amount of lignite washed up on the northern and the western shores after stormy weather, are scarcely valid. The collections from the shores of Anholt show that the lignite occurs together with Katholm erratics of Purbeck-Wealden age. The lignite is ecologically related to Purbeck-Wealden deposits, too.

It is remarkable that the great majority of the Katholm erratics consists of shales and claystones. The reason could be that "Cyrena" and "Paludina" mostly occur in a clay-environment, and thus other erratics have not been determined as Katholm erratics. It is more probable that shale and claystone entirely dominate in the place of origin. Some Katholm erratics, found more scarcely, consist of light sandstone, as well as grey and lightgrey lime-sandstones and grey lime-marlstones, and also contain "Cyrena" in a good condition.

The most common shale is grey to dark grey and often contains some mica. Gottsche (1883) observed that the shale was bituminous.

The distribution of the "Cyrena" erratics (text-fig. 4) shows that the Katholm erratics form a rather undisturbed boulder train from the northeast with the majority of occurrences to the northeast (marked by large dark triangles in the text-figure). The boulder train is situated in the central part of a boulder train consisting of Kinnediabase and radiating from Vestergötland in Western 
Sweden (Gry 1974 and personal communication from Dr. Gry). The largest finds of Katholm erratics marked on the text-fig. 4 are localities with extremely many local finds (Grenå-Katholm, Tirstrup, Æbelø etc.) and with the finds as an assemblage of erratics, as described at Lindø, in Odense Fjord, where the Katholm erratics seem to occur in a till with bottom-striations of mainly north-south direction. This Katholm Till is overlain by a till probably coming from a south-eastern direction (Nielsen 1961, Smed 1962, Andersen 1965).

Many finds of Katholm erratics have been described and discussed in the literature (Gottsche 1883, Grönwall 1904, Jessen 1907 \& 1935, Madsen 1897, 1900 \& 1902, Skeat \& Madsen 1898), mostly in Danish as parts of general regional-geological descriptions.

\section{Geological models related to the area}

As some features in the Kattegat area indicate lateral dissimilarities with other places along the Fennoscandian Border Zone our scarce knowledge of this area gave rise to careful studies of the Fennoscandian Border Zone through Danmark. It was the present author's intention to verify a hypothesis of large-scale strike-slip movements through the area which explains many geological features concerning the Danish Embayment: primarily the Upper Jurassic marine basin and its close relationship to basins in the U.S.S.R. Moreover, other features from Permian to Tertiary, during the time where such hypothetical large-scale strike-slip faults were most probably activated, are also considered. The shape of the Zechstein basin and juxtaposition along some of the fractures may be explained by lateral dislocations. Some of the lateral phenomena from Europe have been included in a global model (e.g. van Bemmelen 1965). Sorgenfrei (1969) in a description of the geological framework of the North Sea area discussed horizontal forces affecting large regions between a system of crustal units, resulting in both vertical and horizontal displacements. He defined some NW-SE trending wrench faults in the basement of the North Sea area as illustrations for a hypothesis of tension rift diapirism.

A long series of distribution models of the consolidated areas in northwestern Europe have been reviewed rather recently by Franke (1967). He subdivides the region in areas consolidated by orogenesis (cf. Stille 1923-1925). Protoeuropa (Ureuropa) is the Fennosarmatia or the East European Platform consolidated during several Precambrian orogeneses. Palaeoeurope (Paläeuropa) consists of Caledonian consolidated areas, and Mesoeurope (Mesoeuropa) includes the areas where the Variscan orogenesis has consolidated the older deposits. He discussed distribution models of Northern Europe by Beyschlag \& Schriel (1925), Stille (1955), Köbel (1950, 1963), v. Gaertner (1960), and Znosko (1964) and pointed out that areas in DDR and in Poland belong 
to the East European Platform without Caledonian "eutectonic" disturbances. It was also shown that Danmark and the southern North Sea area belongs to Protoeurope. Bailey \& Holtedahl (1938) indicate eastern England as a part of the East European Platform. Deep borings in Danmark have verified the view mentioned above (Bruun Christensen 1971).

The North Sea area (North Sea Basin according to Gripp 1933) surrounded by the Fennoscandian Shield in the east and north, the Central European Variscan consolidated blocks in the south and the Caledonian blocks in the west, is one of the most minutely described areas in the world as regards the geology. Many syntheses of different geological aspects or studies of national regions for the area have been produced (e.g. Bölau 1949, Sorgenfrei 1969, Voigt 1963, Baybroek, Haanstra \& Erdman 1967, v. Bubnoff 1952).

The East European Platform is bordered by still younger roots of mountains as the results of orogenesis. The western margin of the East European Platform was somewhat overthrusted by the Caledonian orogenic structures until the Devonian, and Palaeoeurope includes the western part of Norway, most of Scotland, Ireland, Northern England, and Wales. In southern Cornwall, England and in Bretagne, France, the older deposits have not been affected by strong Caledonian disturbances, but the orogenesis has affected the Brabant Massif about 600 kilometres further to the east in Europe. In Czechoslovakia and Poland some of the tectonic disturbances may be part of the Caledonian orogenesis. The boundary between Palaeoeurope and Mesoeurope seems to be rather complex. It cuts Palaeoeurope abruptly and forms an undulating line north of the resistant blocks in the region from southern England to southern Poland. The line is more or less conformable with some of the Alpine orogenic structures ("Neoeuropa"), but seems to diverge towards the Carpathians, as Alpine structures are more or less overthrusting the East European Platform in southeastern Poland. Large juxtapositions along fractures occur in some places in northwest Europe.

These outlines of northern Europe give an oversimplified picture. Knowledge of the deeper structures in the deep basins below and around the North Sea is still scarce, but if the East European Platform has a shape close to the one outlined here, it is opportune to search for large horizontal displacements in the area around the North Sea and in the light of a plate-tectonic pattern.

In plates moving as crust elements (continental plates, micro-plates etc.) fault zones are explained as a result of compressions or tensions from neighbouring plates or as the result of an effect from the deeper surfaces on which the plates move. European plates have been affected by movements in various directions. These movements may result in the formation of huge mountain complexes (e.g. the Caledonides during the Paleozoic) by compression and the 
development of middle-sized basins (e.g. in the North Sea during the Tertiary) by tension.

Different conjugating shear systems in parts of Europe related to the Alpine deformation have been mapped (Pavoni 1969), but our knowledge of Older Tertiary or Mesozoic fractures is very uncertain as these are strongly blurred by younger stress influences. It is characteristic for the northern part of Europe that tectonic activities had a stronger effect on the deposits during Mesozoic than later in Tertiary. Early Kimmerian tectonics during uppermost Triassic and lowermost Jurassic, Late Kimmerian during uppermost Jurassic and lowermost Cretaceous, Sub-Hercynian faulting in Upper Cretaceous, and Laramian disturbances in Lower Tertiary are well recognized tectonic phases in the Danish area, while the later Tertiary deposits have been affected tectonically relatively weakly, though tectonic activities in the Alpine area were rather intense at that time. Probably the stress from the Alpine area was preliminarily harmonized by vertical and horizontal movements combined with a development of the North Atlantic Ocean. Later the stress was neutralized by "eutectonic" activities in the Carpathians and the Alps.

Since the Permian, most of the tectonic activities in Europe seem to be explainable by two main causes: collisions between African plates and European plates relatively eastwards (or northwards) away from American plates resulting in the development of the Atlantic Ocean.

In southern Europe, African or European micro-plates (e.g. Sardinia, Corsica, and Iberia) seem to have been displaced or rotated by different forces at different times as the result of collisions between continental plates. Few structures in continental northern Europe have been connected with these large-scale plate tectonics in southern Europe. For the North German-Polish depression six structural models with some relations to both horizontal and vertical movements have been evaluated recently, but none of these models was regarded as being dominant at present (Orszak \& Thierback 1973). This paper and a later one (Thierback 1974) contain much valuable evaluation and information.

Large rotations of blocks in northern Europe are probably not possible though more space between the blocks has been present. Many geological features preclude larger rotations (e.g. palaeomagnetic), but large-scale lateral displacements such as strike-slip faults from southern Europe into northern Europe and from the Atlantic into western Europe is a relatively simple hypothetical model for verification.

Some important geological features in northwestern Europe may well be explained as results of a confusion of block distribution in the area. Using recent models for horizontal displacements of the same scale (e.g. San Andreas Fault system in western U.S.A.) it appears that micro-plates (blocks) have been moved in a northwestern direction during Mesozoic times (e.g. along parts of 
the Fennoscandian Border Zone) and along possibly younger transcurrent fault zones (e.g. the Charley-Gibbs Fracture Zone through southern Great Britain into structurally weak zones in the continent between Protoeurope and Mesoeurope towards the Carpathian).

This model implies plate-tectonics for northern Europe connected to the Alpine orogeny and the development of the North Atlantic Ocean. Stress in European blocks may be effected and controlled by a northern or relatively eastern movement of the European continental plate in which different masses move by different routes. Tensions west of most consolidated blocks have to be a tectonic result before stabilization. Old trenching along boundaries to the East European Platform is a rather uncertain possibility.

An important structural feature crossing the Fennoscandian Border Zone is the Oslo Graben. It has been interpreted as part of a rift valley system with other graben structures in Europe. Stille (1923-1925) pointed out the possibility of a connection between the Oslo Graben, the Rhine Graben, and the Rhone Graben and defined the structure Mittelmeer-Mjösen Zone through Europe. Later borings into the deeper deposits in North Germany and in Danmark have shown that no direct connections between the Oslo Graben and the Rhine Graben were present below the thick sediment cover. Later investigators have studied the deposits in the area with the hypotheses of Stille in mind.

Other graben structures interpreted as rift valleys have been found in Northern Europe from Great Britain to northern Sweden. Nearly all of them have a $\mathrm{N}-\mathrm{S}$ direction (the Rhine trend), but have been activated at different times at least since Permian. The direction of the Mittelmeer-Mjösen Zone seems to be based on a Variscan shear zone cutting the Variscan strike, and in the Oslo Graben the majority of small-scaled faults are dextral (Bederke 1970). The Rhine Graben has been interpreted as a sinistral shear system interacting with a NW-SE dextral shear system caused by the Alpine deformations (Pavoli 1969). Close to the Alps the separation of the graben structures in segments has been explained by Illies (1972) as a result of transform faulting.

Along the Norwegian west coast a north-south zone of earthquakes is recognized. West of this, a zone with thin crust has been mapped between the Norwegian Caledonides and the Scottish Caledonides in the northern North Sea graben structures (Howitt 1974). These graben structures (Viking Graben and perhaps parts of the Central Graben) may originally have been shaped as segments of an old rift valley system, the Mittelmeer-Mjösen Zone (named by Stille), but reset along large transform fracture zones. Close to the Fennoscandian Border Zone, a transcurrent fault zone has been illustrated by van Bemmelen (1965) as continuing and transforming the continent. Many dextral fault zones can be located close to and southwest of the Fennoscandian Border 
Zone. Further to the southwest, at least southwest of the Ringkøbing-Fyn High and the East Elben Massif, sinistral fault zones have been recognized (Sorgenfrei 1969). The transform fractures were probably activated during the Middle Mesozoic, as indicated by later transcurrent faults.

Time differences in the development of rift valley segments, with faults in many directions including a series of parallel faults on each side of the rifts, are indicated by the volcanic activities close to these old structures, the Oslo Graben during Lower Permian, the Viking Graben during Middle Mesozoic and the Rhine Graben during Tertiary. 


\section{Dansk sammendrag}

\section{Bidrag til fortolkningen af Den fennoskandiske Randzone}

Nogle resultater af fortolkninger over seismiske data fra Kattegat, S. Øresund og V.Østersøen (J. C. Baartman)

Fortolkningen af reflektionsseismiske data fra Kattegat viser resultaterne af tektoniske bevægelser, som har fundet sted lige fra præ-jurassisk tid til nyere tid.

I Kattegat finder man fortsættelsen af randzonen fra Skåne i et bredt bælte i nordvestlig retning. Dette bælte viser sig at bestå af blokke, begrænsede af forkastninger, som kan påvises helt ned i grundfjeldet. Randzonen synes at udviskes mod NV.

Den strukturelle udvikling, som blev resultatet af den sen-kimmeriske orogenese, gav anledning til aflejring af tykke jurassiske lagserier, specielt i den vestlige del af Kattegat og i nærheden af Øresundsregionen. En tærskel, som i hovedsagen indeholder jurassiske lag og som stryger i SSV-lig retning fra Anholt, delte hovedbassinet i Kattegat i mindre sedimentationsbassiner, der var delvis åbne i kridttiden.

I det sydlige Øresund synes store N-NV strygende blokke, begrænsede af forkastninger ned i grundfjeldet, at være dannet i forbindelse med de tektoniske bevægelser i Den fennoskandiske Randzone.

\section{Geologiske trak af Den fennoskandiske Randzone (O. Bruun Christensen)}

Den fennoskandiske Randzone fremtræder som en overgangszone mellem et højtliggende grundfjeldsområde mod nordøst (Det fennoskandiske Skjold) og relativt dybtliggende bassinområder mod sydvest (Det danske Sænkningsområde, Det nordtyske Sedimentationsbassin etc.). I de dybere bassinområder skiller relative højdeområder de enkelte delbassiner. Ringkøbing-Fyn Højderyggen er således den centrale del af et højdeområde, som strækker sig fra den centrale del af Nordsøen gennem Sydvest-Danmark og ind i DDR og Polen. Højdeområdet består af mere eller mindre isolerede blokke, som almindeligvis er forskudt en del i forhold til hinanden.

I Den fennoskandiske Randzone kan den strukturelle opbygning direkte studeres i Skåne, hvor grundfjeldet som horste når op gennem yngre aflejringer. Den samme opbygning kan også forventes at være tilstede andre steder langs Den fennoskandiske Randzone. Det er imidlertid karakteristisk, at permiske aflejringer ikke har en større udbredelse langs Den fennoskandiske Randzone, skønt yngre aflejringer ofte breder sig ind over denne. De permiske aflejringer 
og specielt zechstein evaporiternes udbredelse giver et godt billede af bassinforholdene efter de variskiske tektoniske forstyrrelser, som må forventes at have påvirket de ældste aflejringer i området.

Text-fig. 3 er et skematisk og noget hypotetisk snit gennem Jylland fra syd til nord i bassinernes dybere dele. Præ-zechstein aflejringer er kun kendt i ringe grad, og i den dybeste del af Det danske Sænkningsområde må grundfjeldet findes i en dybde på ca. 5-8 km. I dette område er det dybtliggende zechsteinsalt blevet mobilt og trængt op i de overliggende lag som salthorste eller -domer. I modsætning til Den fennoskandiske Randzone er strukturer i de yngre aflejringer formodentligt på grund af tilstedeværelse af zechstein evaporiter af særlig beskaffenhed.

De seismiske undersøgelser af strukturerne på tværs af Det danske Sænkningsområde fra et strukturelt højtliggende område ved Møn og Rügen mod Øresund og Skåne under Østersøen viser uhyre blokstrukturer af kaledonisk og variskisk oprindelse. I dette område er der ikke iagttaget forekomster af zechstein-salt. Som en forlængelse af Ringkøbing-Fyn Højderyggen kan der afgrænses en Møn-Arkona Blok med relativt højtliggende grundfjeld svagt hældende mod syd-sydvest. På denne blok tynder de palæozoiske aflejringer ud mod nord og de yngste palæozoiske dannelser fra zechstein og karbon synes ikke at være tilstede nord for en kraftig V-Ø strygende forkastningszone fra nordsiden af Møn til nord for Rügen. Et dybt nedsænket og blokforkastet område mellem Møn-Arkona Blokken og Romele Åsen i Skåne er sandsynligvis udfyldt overvejende med siluriske og mesozoiske aflejringer over stærkt forkastet grundfjeld.

Den fennoskandiske Randzones nordlige forlængelse i Skagerrak-området er ikke klarlagt. Højtliggende grundfjeld i den nordøstlige del af Vendsyssel (Vendsyssel Højdeområdet) synes strukturelt at være sammenhørende med de områder langs den svenske kyst, hvor de sengothiske Bohus graniter er udbredt. Vendsyssel Højdeområdet er adskilt fra den dybere del af Det danske Sænkningsområde ved en kraftig forkastningszone, hvoraf Vrå Forkastningen langs Rønnebjerg Gravsænkningen er vist på text-fig. 3.

Gennem de seismiske undersøgelser kan Den fennoskandiske Randzone følges som en højtliggende struktur i øvre kridt fra Vendsyssels sydlige del tværs gennem Kattegat umiddelbart syd for Anholt ind mod Sjælland og Skåne. En kraftig fleksur i den nordlige del af Øresund (Helsingborg-Helsingør Fleksuren) er overvejende af kretacisk alder. Tydelige vinkeldiskordanser og andre tektoniske elementer her og i Skåne angiver forstyrrelse af tidlig- og sen-kimmerisk, sub-hersynisk og laramisk alder.

På basis af det seismiske strukturkort for Kattegat området over ældste dele af de øvre kretaciske aflejringer må det hævede område gennem det centrale Kattegat anses for strukturelt meget beslægtet med den såkaldte Helsingborg- 
Romelehorst Ryg i Skåne. Dette strøg og områderne snævert nordøst herfor frem til Kullen og Vombsænkningen har nogenlunde den samme bredde som området i det sydøstlige Kattegat, mens området i den nordvestlige del er betydelige bredere. Dette må sandsynligvis sættes i forbindelse med zechsteinbassinets udbredelse. I nordvest er de mesozoiske aflejringer foldede og delvis blokforkastede. Aksekulminationer og -depressioner er noget svagere men meget lig de, der kan iagttages i det overvejende blokforkastede Skåne. Umiddelbart syd for området i Kattegat og i Nørrejylland findes de største mægtigheder af triassiske og øvre kretaciske aflejringer. Nord for disse områder er aflejringer meget tyndere, mens de jurassiske og nedre kretaciske derimod lokalt kan være tykkere mod nord.

En NNØ-SSV-gående forkastet fleksur øst for Anholt må sandsynligvis sættes i forbindelse med tektoniske elementer i de gothiske og prægothiske dannelser. Fleksurens fortsættelse mod Sjælland i det sydlige Kattegat kan ikke følges i de seismiske profiler ved basis af de øvre kretaciske dannelser. Området vest for fleksuren mod Vendsyssel Højdeområdet synes at udgøre en enhed. De kvartære aflejringer er relativt tykke. Omkring Anholt er de kvartære dannelser direkte pålejret aflejringer af nedre kretasisk alder ligesom ved Skagen. Desuden har de jurassiske og de triassiske dannelser ved Anholt været udsat for glacialerosion under de kvartære istider. Text-fig. 4 viser et fordelingsmønster over fund af Katholmblokke, som her er benævnelse for istransporterede blokke med fossiler af "Cyrena"-typer og som kan vises at være af purbeckien alder. De er vidt forskellige fra andre dannelser fra øvre jura i Nordjylland. Katholmblokkene har tidligere været anset for at være af oligocæn alder.

I et afsnit fremlægges en geologisk model for området i øvrigt uden nogen form for verifikation. I forbindelse med flere hypoteser, nær tilknyttet teorier om kontinentalforskydninger og pladetektonik, har undersøgelserne af Den fennoskandiske Randzone været nødvendige. Forfatteren anser store laterale forskydninger langs Den fennoskandiske Randzone for meget mulige, og disse vil kunne forklare ligheder til fjerntliggende bassiner. Forfatteren forestiller sig, at "rift"-gravsænkninger i den nordlige centrale del af Nordsøen oprindelig har været dele af en "Mittelmeer-Mjøsen Zone", forskudt i forbindelse med den begyndende alpine orogenese og den initiale åbning mellem kontinentalpladerne omkring Det nordatlantiske Ocean. 


\section{Literature}

Andersen, S. T. 1965: Pollen Analysis and Till Stratigraphy at Lindø, Denmark. - Geol. Soc. America, Spec. Paper, 84, pp. 65-78.

Baartman, J. C. 1973: Interpretation of reflection seismic work in the area around Nøvling No. 1. - Danm. geol. Unders. III række (40), pp. 34-62.

Bailey, E. B. \& Holtedahl, O. 1938: Northwestern Europe Caledonides. - Regionale Geologie des Erde, 2, 2. - Leipzig.

Becksmann, E. 1931: Die Verteilung der Schollen im norddeutschen Diluvien in ihrer Lagebeziehung zu den geophysikalischen Anomalien. - Zeitsch. Geschiebeforschung, 7 (1), pp. 26-33.

- 1933: Warum gibt es eine Cimbrische Halbinsel? - Naturwissensch. Ver. SchleswigHolstein, 10 (1), 6 pp.

Behrens, S. 1973: Analyses of the Physiography of Scania and Sealand interpreted by means of Erts-images. - Swedish Geographical Yearbook 1973, 49, pp. 139-147.

Bemmelen, R. W. van 1965: The Evolution of Mega-Undations. A Mechanical Mode for Large-scale Geodynamic Phenomena. - In "The World Rift System", Geol. Surv. Canada, Paper 66-14, pp. 373-399.

Bergström, J., Christensen, W. K., Johansson, C. \& Norling, E. 1973: An extension of Upper Cretaceous rocks to the Swedish west coast at Särdal. - Bull. geol. Soc. Denmark, 22, pp. 83-154.

Bergström, J. \& Johansson, C. 1973: Upper Cretaceous rocks at Särdal. - Bull. geol. Soc. Denm. 22, pp. 83-90.

Bergström, S. M. \& Nilsson, R. 1974: Age and correlation of the Middle Ordovician bentonites on Bornholm. - Bull. geol. Soc. Denmark, 23, pp. 27-48.

Beyschlag, F. \& Schriel, W. 1925: Kleine Geologische Karte von Europa. - Berlin.

Brotzen, F. 1940: Flintrännans och Trindelrännans geologi. - Sver. Geol. Unders. C 435, $33 \mathrm{pp}$.

- 1945: De geologiska resultaten från borrningarna vid Höllviken, Del I. - Sver. Geol. Unders. C 465, 64 pp.

- 1950: De geologiska resultaten från borrningarna ved Höllviken, Del II. - Sver. Geol. Unders. C 505, 48 pp.

- 1960: The Mesozoic of Scania, southern Sweden. - Int. Geol. Congr. XXI Sess. Guide to Excursions A21 and C16.

Bubnoff, S. von 1943: Der Südrand Skandinaviens. - Geol. Randschau 34, pp. 197-208.

- 1952: Fennosarmatia. (Geologische Analyses des europäischen Kerngebietes). - 450 p. Berlin.

Bylund, S. 1974: Palaeomagnetism of dykes along the southern margin of the Baltic Shield. - Geol. Fören. Stockh. Förh. 96, pp. 231-235.

Bölau, E. 1951: Recent tectonics and the Rhaetic sedimentation in N.W. Scania. - Geol. Fören. Stockh. Förh. 73 pp. 
- 1959: Der Südwest- und Südostrand des Baltischen Schildes (Schonen und Ostbaltikum), - Geol. Fören. Stockh. Förh. 81 (2), pp. 167-230.

- 1969: Tektonische Tiefenbau und glazigene Stauchungserscheinungen im Skrombergagebiet (Nordwest Schonen). - Geol. Fören. Stockh. Förh. 91, pp. 457-478.

- 1969: Tektonische und klimatische Ausdeutung von Faziesgegensätzen im Rhät Schonens. - Geol. Fören. Stock. Förh. 91, pp. 561-573.

- 1972: Genese und Alte der Horste Schonens. - Geol. Fören. Stockh. Förh. 94, pp. 411-422.

- 1973: Die kimmerischen Bewegungen im tektonischen Bilden Schonens. - Geol. Fören. Stockh. Förh. 95, pp. 165-180.

Carsten, V. \& Hirschleber, H. 1969: Seismic Measurements in Jylland 1969. - Zeitschrift für Geophysik, 37.

Christensen, O. Bruun 1971: Nedre Karbon i dybdeboringen Ørslev nr. 1 på Falster (English summary). - Danm. geol. Unders. Report No. 5, 24 pp.

- 1971b: Øvre silur i dybdeboringen Nøvling nr. 1 (English Summary). - Danm. geol. Unders. Report No. 7, 24 pp.

- 1973: The Rønde and Nøvling Formations (Silurian) in Nøvling No. 1. - Danm. geol. Unders. III række, (40) pp. 150-157 ( in Danish with English summary).

Dadlez, R. 1974: Some geological problems of the Southern Baltic Basin. - Acta Geol. Polonica, 24 (1) pp. 261-275.

Flodén, T. 1973: Notes on the bedrock of the eastern Skagerrak with remarks on the Pleistocene deposits. - Stockh. Contr. Geol. XXIV, pp. 79-102.

Franke, D. 1967: Der erste Aufschluss im tieferen Paläozoikum Norddeutschlands und seine Bedeutung für die tektonische Gliederung Mitteleuropas. - Jb. Geol. pp. 119-165.

Gaertner, H. R. von 1960: Über die Verbindung der Bruchstücke des kaledonischen Gebirges in nördlichen Mitteleuropa - Internat. Geol. Congr. Norden, 21 (19) pp. 96-101.

Golub, D. P. \& Sidorov, Y. S. 1971: The surface Structure of the Precambrian Basement of the Baltic Sea (Based on Magnetic Survey Data of the R/V Zarya). - Oceanography, 11 (1), pp. 195-199.

Gottsche, C. 1883: Die Sedimentaer-Geschiebe der Provinz Schleswig-Holstein. - Yokohama, pp. 1-66. - (Reprint 1966, Der Geschiebe-Sammler. - Mitt. Sammelergruppe für Geschiebekunde in Naturwissenschaftlichen Verein Hamburg, 1\&2).

Gripp, K. 1933: Geologie von Hamburg. - 144 p. Hamburg.

Gry, H. 1960: Geology of Bornholm. Int. Geol. Congr. XXI Sess. Guide to excursions A45 and C40.

- 1974: Ledeblokkes kornstørrelsesforhold og transportmåde. - Dansk geol. Foren. Årskrift 1973, pp. 140-151.

Grönwall, K. A. 1904: Forsteningsførende Blokke fra Langeland, Sydfyn og Ærø samt Bemærkninger om de ældre Tertiærdannelser i det baltiske Område. - Danm. geol. Unders. II række, (15), 62 p.

Haug, E. 1921: Traité de Géologie, I; Les phénomènes géologiques. - Paris.

Hansen, K. 1941: Tektoniske Retningslinier på Sjælland. - Meddr. Dansk geol. Foren., 10 (9), pp. 9-16.

- 1943: Tektoniken i Danmarks Undergrund endnu en gang. - Meddr. Dansk geol. Foren. 10, pp. 367-374.

Heybroek, P., Haanstra, U. \& Erdman, D. A. 1967: Observations on the geology of the North Sea area. - Seventh World Petrol. Congr. Proc. 2, pp. 905-916.

Hirschleber, H., Hjelme, J. \& Sellevoll, M. 1966: A Refraction Profile through the Northern Jutland. - Geodætisk Institut, Medd. No. 41, pp. 1-33.

D.G.U. II. rk. nr. 102 
Holtedahl, H. \& Sellevoll, M. A. 1971: Geology of the continental margin of the eastern Norwegian Sea and of the Skagerrak. - Inst. Geol. Sciences, Report No. 70/14, pp. 35-52.

Holtedahl, O. 1964: Echo-sounding in the Skagerrak. - Norges geol. Unders. 223, pp. $139-160$.

Howitt, F. 1974: North Sea oil in a world context. - Nature, 249, pp. 700-703.

Illies, J. H. 1972: The Rhine Graben Rift System - Plate Tectonics and Transform Faulting. - Geophysical Surveys, 1 (1).

Jentzsch, A. 1888: Über die neueren Fortschritte der Geologie Westpreussens. - Schrift. naturforsch. Ges. Danzig, N.F. 7 (1), pp. 1-25.

Jessen, A. 1897: Kortbladene Læsø og Anholt. (Résumé en français). - Danm. geol. Unders. I række (4), 48 pp.

- 1907: Kortbladet Skamlingsbanke. (Résumé en français). - Danm. geol. Unders. I række (12), 99 pp.

- 1935: Kortbladet Haderslev. (Résumé en français). - Danm. geol. Unders. I række(17), 95 pp.

King, R. E. 1973: Petroleum Exploration and Production in Europe in 1972. - Bull. Am. Ass. Petrol. Geol. 57/10, pp. 1934-1989.

Köbel, H. 1959: Stand und Ergebnissen der Kartierung des tieferen Untergrundes Nordostdeutschlands und angrenzender Gebiets. - Ber. geol. Ges. DDR, 4, pp. 115-156.

- 1963: Der grundgebirgsbau Nordostdeutschlands in Gesamtrahmen der bemachbarte Gebiete. - Geologie, 12, pp. 674-682.

Larsen, B. 1972: Structure of the Fennoscandian Border Zone in the Southern Baltic Sea Bornholm Area. - Unpubl. report, Institute for Applied Geology, Danm. Polytekniske Læreanstalt.

Larsen, G. 1966: Rhaetic-Jurassic-Lower Cretaceous Sediments in the Danish Embayment (A Heavy-Mineral Study). - Danm. geol. Unders. II række (91), 128 p.

- Christensen, O. Bruun, Bang, I. \& Buch, A. 1968: Øresund, Helsingör-Helsingborg Linien. - Danm. geol. Unders. Rapp. 1, 90 p.

Larsen, O. 1972: Kalcium/Argon dateringen af prøver fra danske dybdeboringer. Dansk geol. For. Årssk. 1971, pp. 91-94.

Lidmar-Bergström, K. 1973: Tectonic Analysis of South-Western Sweden by means of Erts Images. - Swedish Geographical Yearbook 1973, 49, pp. 125-133.

Lind, G. 1967: Gravity measurements over the Bohus granite in Sweden. - Geol. Fören. Stockh. Förh. 88, pp. 542-548.

Lindström, M. 1967: Om den tektoniska utvecklingen av Skånes paleozoikum. - Meddr. Dansk geol. Forening, 17, pp. 163-165.

- 1967: "Funnel Grabens" and Early Paleozoic Tectonism in South Sweden. - Geol. Soc. Amer. Bull. 78, pp. 1137-1154.

Lundegårdh, P. H., Lundquist, J. \& Lindström, M. 1964: Berg och jord i Sverige. -344 p. Stockholm.

Lundgren, B. 1882: Studier öfver fossilförande lösa block. - Geol. Fören. Stockh. Förh. 6, pp. 31-34.

- 1891: Studier öfver fossilförande lösa block. - Geol. Fören. Stockh. Förh. 13, pp. 111-121.

Madsen, V. 1897: Kortbladet Samsø (Résumé en français). - Danm. geol. Unders. I række (5), $87 \mathrm{p}$.

- 1900: Kortbladet Bogense (Résumé en français). - Danm. geol. Unders. I række (7), $112 \mathrm{p}$. 
- 1902: Kortbladet Nyborg (Résumé en français). - Danm. geol. Unders. I række (9), $182 \mathrm{p}$.

Mulder, F. G. 1971: Paleomagnetic Research in some Parts of Central and Southern Sweden. - Sver. Geol. Unders. C 653, 56 p.

Mörner, N. A. 1969: The Late Quaternary History of the Kattegat Sea and the Swedish West Coast. - Sver. Geol. Unders. C 640, 35 p.

Nathorst, A. G. 1894: Sveriges Geologi. - 336 p. Stockholm.

Nielsen, A. V. 1961: Lindø, et af Keld Milthers sidste kvartærgeologiske arbejdsfelter. Meddr. Dansk geol. Foren. 14, pp. 453-454.

Noe-Nygaard, A. 1963: The Precambrian in Denmark. In Rankana (edit.): The Precambrian 1, London.

- 1967: Dredged Basalt from Skagerrak. - Meddr. Dansk geol. Foren. 17, pp. 285-287.

Norling, E. 1970: Jurassic and Lower Cretaceous stratigraphy of the Rudebäck -Fortuna borings in southern Sweden. - Geol. Fören. Stockh. Förh. 92.

Olszak, G. \& Thierbach, H. 1973: Einige geologisch-geophysikalische Strukturelemente der Norddeutsch-Polnischen Senke und ihre möglichen Beziehungen zu Tiefenbau und Entwicklung dieses Krustenabschnitts. - Z. geol. Wiss. 1 (2), pp. 155-172.

Pavoli, N. 1969: Zonen lateraler horizontaler Verschiebung in der Erdkruste und daraus ableitbar aussagen zur globalen Tektonik - Geol. Rundsch., 59 (1), pp. 56-77.

Poulsen, C. 1974: Further contributions to the knowledge of the Paleozoic of Slagelse No. 1, Western Sealand. - Danm. geol. Unders. II række (101), 42 pp.

Poźaryski, W. 1966: Geological Map of Poland without the Cenozoic Deposits. - Instytut Geol. Warszawa.

Printzlau, I. \& Larsen, O. 1972: K/Ar age determinations on alkaline olivine basalt from Skåne, southern Sweden. - Geol. Fören. Stockh. Förh. 94, pp. 259-269.

Ramberg, I. B. 1972: Crustal Structures across the Permian Oslo Graben from Gravity Measurements. - Nature Phis. Science, 240, pp. 149-153.

- \& Smithson, S. B. 1971: Gravity Interpretation of the southern Oslo Graben and adjacent Precambrian Rocks, Norway. - Tectonophysics, 11, pp. 419-431.

Rasmussen, L. B., Dinesen, A., Henriksen, S. E., Bang, I., Stenestad, E., Buch, A., Christensen, O. B., Michelsen, O. \& Jacobsen, F. L. 1971: Dybdeboringen Rønde nr. 1 på Djursland. - Danm. geol. Unders., III række, 39, 123 p.

Rasmussen, L. B. 1972: Oversigt over dybdeboringerne på dansk landområde 1965-68. Dansk geol. Foren., Årsskrift for 1971, pp. 41-48.

- , Baartman, J. C., Henriksen, S. E., Kristoffersen, F. N., Dinesen, A., Bang, I., Stenestad, E., Buch, A., Christensen, O. B., Michelsen, O., Hansen, T. J. \& Jacobsen, F. L. 1973: Dybdeboringen Nøvling nr. 1 i Midtjylland. - Danm. geol. Unders. III række, 40, 164 p.

- 1974: Some geological results from the first five Danish exploration wells in the North Sea. - Danm. geol. Unders. III række 3 (42), 46 p.

Regnéll, G. 1967: På gränsen mot kontinenten. - Sver. Natur 2 (67), pp. 54-58.

- \& Ernold Hede, J. 1960: The Lower Paleozoic of Scania. The Silurian of Gotland. Int. geol. Congr. XXI Sess. Guide to Excursions A22 and C17.

Rosenkrantz, A. 1931: Jordskorpebevægelse i Yngre Danien-Tid indenfor Øresundsområdet. - Meddr. Dansk geol. Foren. 8, pp. 138-139.

- 1937: Bemærkninger om det østsjællandske Daniens Stratigrafi og Tektonik. Meddr. Dansk geol. Foren. 9.

- 1939: Bidrag til de danske Juraaflejringers Stratigrafi. - Meddr. Dansk geol. Foren., 9, pp. 526-528. 
- 1942: Om de strukturelle Forhold i den prækvartære Undergrund i Østsjælland. Meddr. Dansk Geol. Foren. 10, pp. 152-158.

Samuelsson, L. 1971: The Relationship between Permian Dikes of Dolerite and Rhomb Porphyry along the Swedish Skagerrak Coast. - Sver. Geol. Unders. C 663, 51 p.

Sellevoll, M. 1968: Report on crustal studies in Norway. - Rept. Intern. Upper Mantle Comm., Leningrad, $12 \mathrm{p}$.

Skeat, E. \& Madsen, V. 1898: On Jurassic, Neocomian and Gault Boulders found in Denmark. - Danm. geol. Unders. II række (8).

Smed, P. 1962: Studier over den fynske øgruppes glaciale landskabsformer. - Meddr. Dansk Geol. Foren. 15, 74 p.

Sorgenfrei, T. 1945: Træk af Alnarp Dalens geologiske Opbygning. - Meddr. Dansk Geol. Foren. 10, pp. 617-630.

- 1951: Oversigt over prækvartærets topografi, stratigrafi og tektonik i området FynSydsjælland-Lolland-Falster-Møn. - Meddr. Dansk Geol. Foren. 12, pp. 166-171.

- 1966: Strukturgeologischer Bau von Dänemark. - Geologie 15 (6), pp. 641-660.

- 1969: Geological Perspectives in the North Sea Area. - Bull. Geol. Soc. Denmark, 19, pp. 160-196.

- 1969: A Review of Petroleum Development in Scandinavia. - In: The Exploration for Petroleum in Europe and North Africa, pp. 191-208.

- \& Buch, A. 1964: Deep Tests in Denmark 1935-1959. - Danm. geol. Unders. II række (36), $146 \mathrm{p}$.

Stille, H. 1923-1925: Rheinische Gebirgsbildung im Kristianiagebiete und in Westdeutschland. - Abh. Preussischen Geol. Landesamt. NF, 95, pp. 110-132.

- 1955: Das mitteleuropäische variszische Grundgebirge im Bilde des gesamteuropäischen. - Geol. Jb., Beih., 2, $138 \mathrm{s.}$

Stolley, E. 1897: Einige neue Sedimentärgeschiebe aus Schleswig-Holstein und benachbarten Gebieten. - Schriften naturw. Ver. Schleswig-Holstein, 9 (1), pp. 77-80.

Strømer, L. 1967: Some Aspects of the Caledonian Geosyncline and Foreland West of the Baltic Sea. - Q. Jl. geol. Soc. Lond. No. 491, 123 (3), pp. 183-214.

Tamrazyan, G. P. 1969: Earthquakes and Cosmic Conditions in the Southern Part of Scandinavia. - Bull. geol. Soc. Denmark, 19, pp. 227-235.

Thierbach, H. 1971: Zur Tektonik des Raums zwischen Ostsee und Schwarzem Meer. Geologie, 20 (2), pp. 95-206.

Tornquist, A. 1908: Die Feststellung des Südwestrandes des baltisch-russischen Schildes und die geotektonische Zugehörigkeit der ostpreussischen Scholle. - Schr. phys.-ökon. Ges. 49, 12 p.

- 1910: Geologie von Ostpreussen. - 231 p. Berlin.

Torske, T. 1972: Tertiary oblique uplift of Western Fennoscandian; crustal warping in connection with rifting and break-up of the Laurasian continent. - Norges Geol. Unders., 273, pp. 43-48.

Troedsson, G. 1951: On the Högenäs Series of Sweden. - Lunds Univ. Årsskr. N.F. Avd. 2, 47 (1), pp. 13-132.

Voigt, E. 1963: Über Randtröge vor Schollenrändem und ihre Bedeutung im Gebiet der Mitteleuropäischen Senke und angrenzender Gebiete. - Zeitsch. deutsch. geol. Ges. 144, pp. 378-418.

Znosko, I. 1964: Zur Frage der Südwestgrenze der präkambrischen Plattform Osteuropas. - (In Russian) Bull. Moscow. ob., I.P., N.S., 69, Geol., 39, pp. 19-34.

Ødum, H. 1935: Træk af den prækvartære Undergrunds Geologi paa Sjælland m.v. Meddr. Dansk Geol. Foren. 8, pp. 516-522. 
- 1971: Danium og maastrichtium på Skanörhalvön. - Sver. Geol. Unders. C 659, 13 p. Åm, K. 1973: Geophysical indications of Permian and Tertiary igneous activity in the Skagerrak. - Norges geol. Unders. 287, 25 p. 


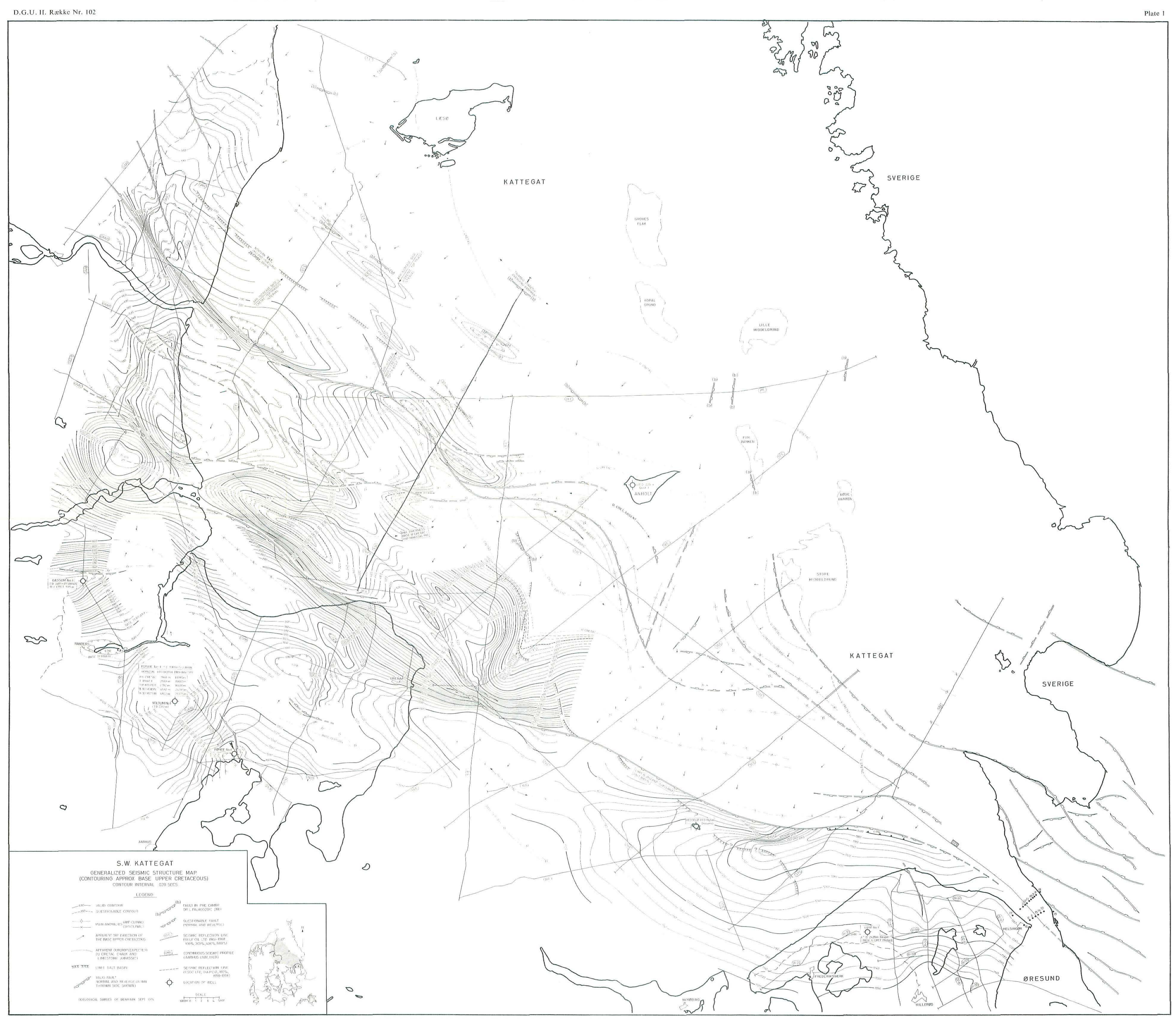



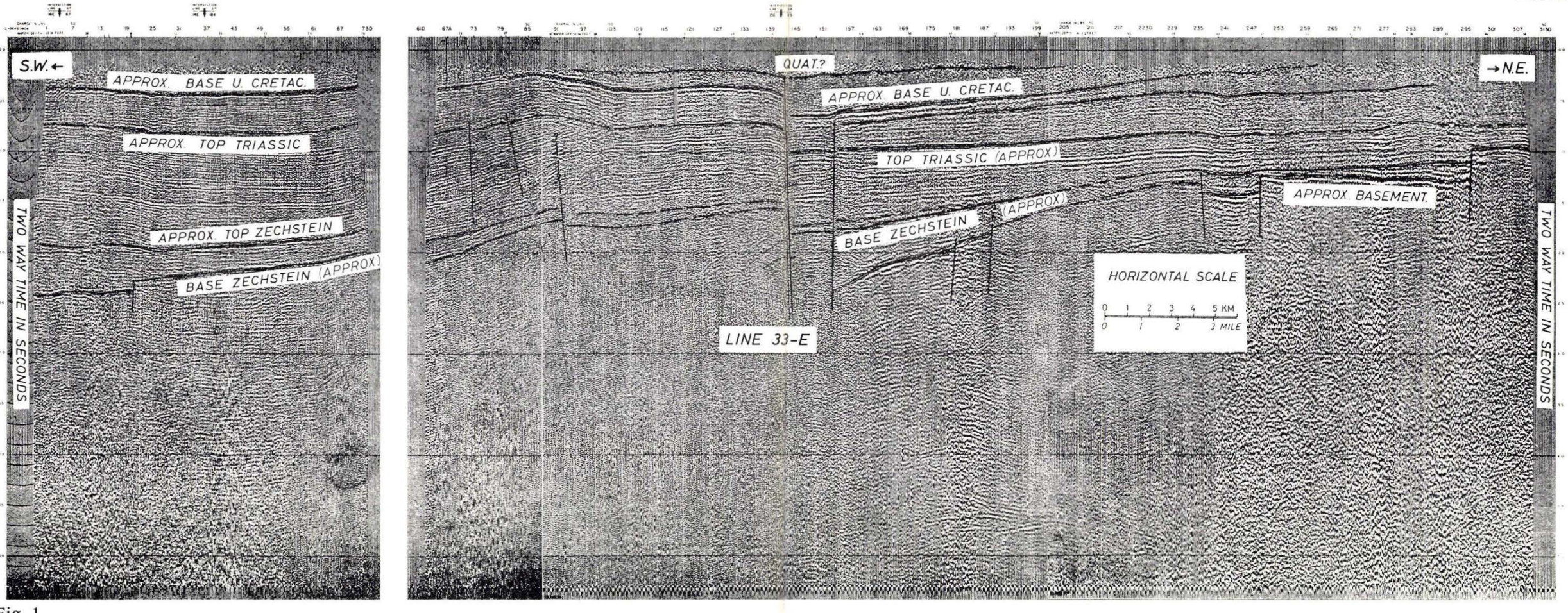

Fig. 1

Figs. 1 and 2. Lines $32 \mathrm{E}$ and $33 \mathrm{E}$ (Plate 1) showing regional thickening of the Lower Cretaceous-Jurassic interval, the Permian onlap of older Palaeozoic rocks and a strongly faulted basement (Pre-Cambrian) at line 33E situated W. of the island of Anholt.

1

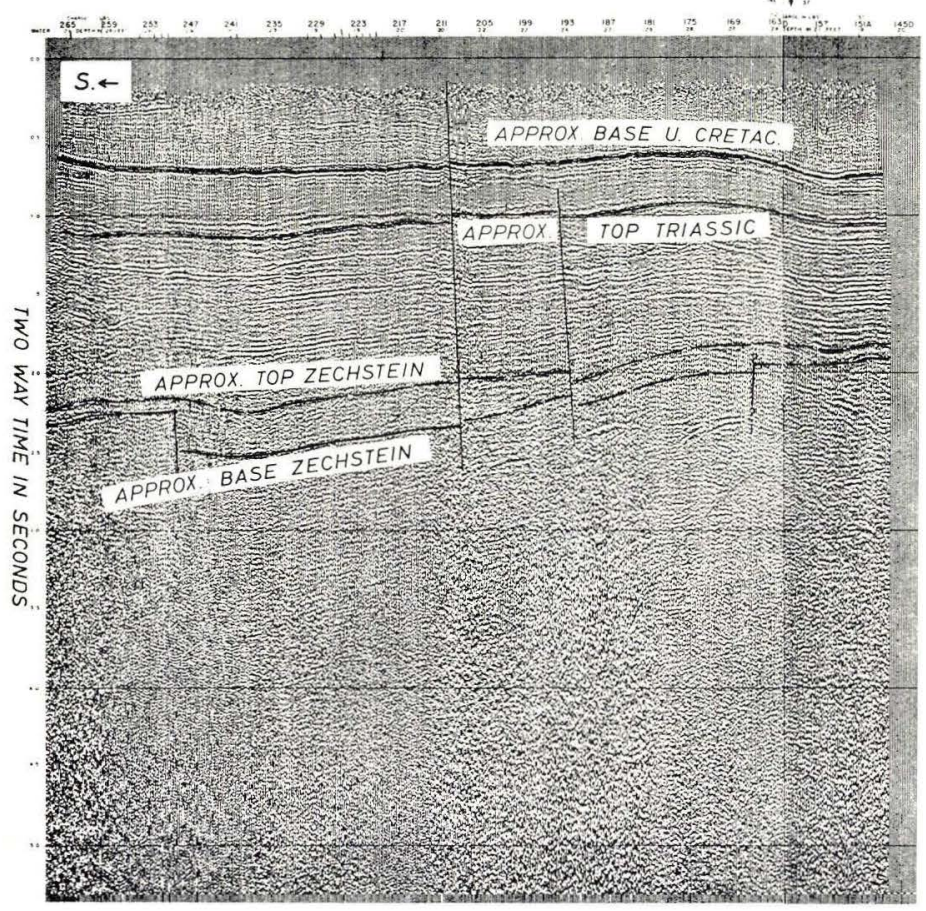

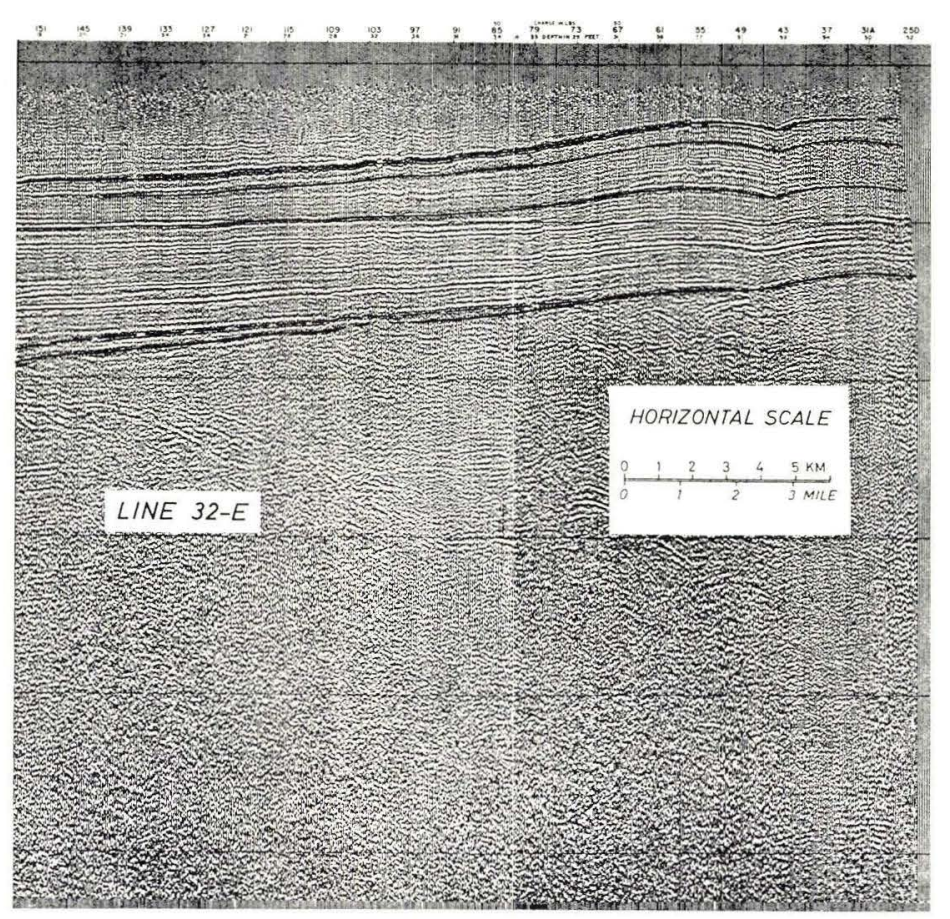

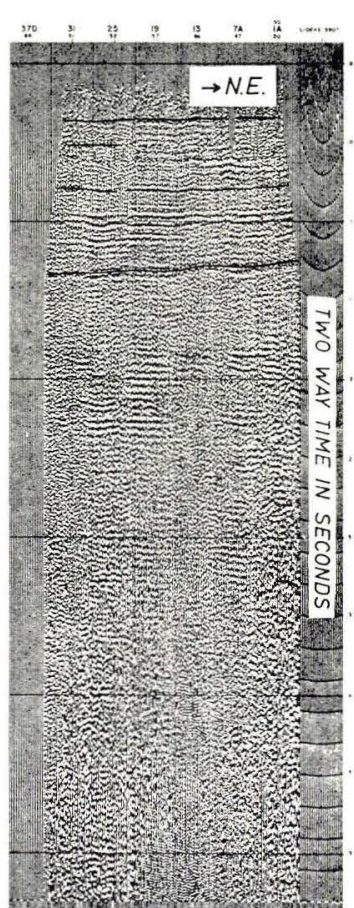

Fig. 2 


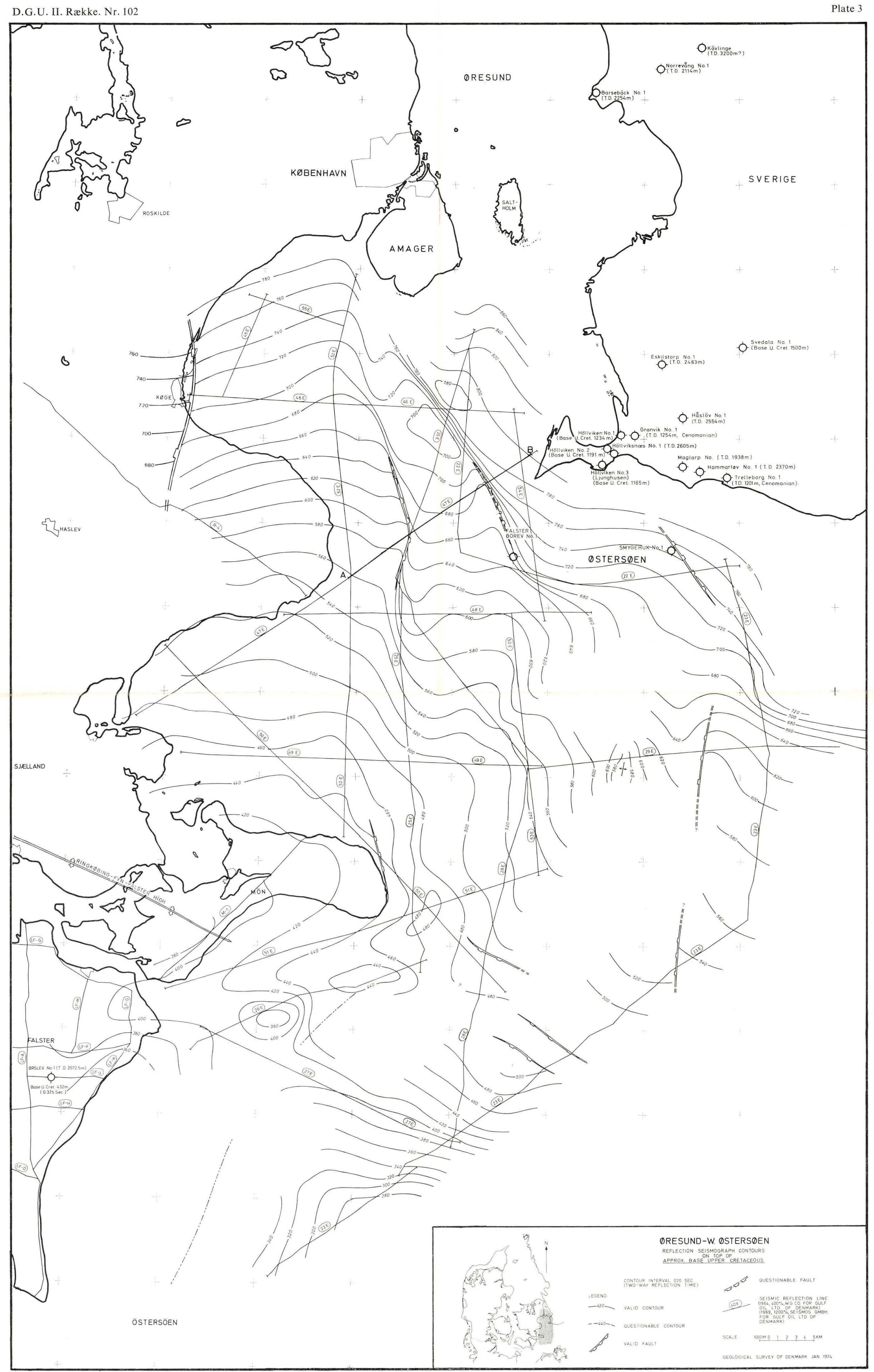




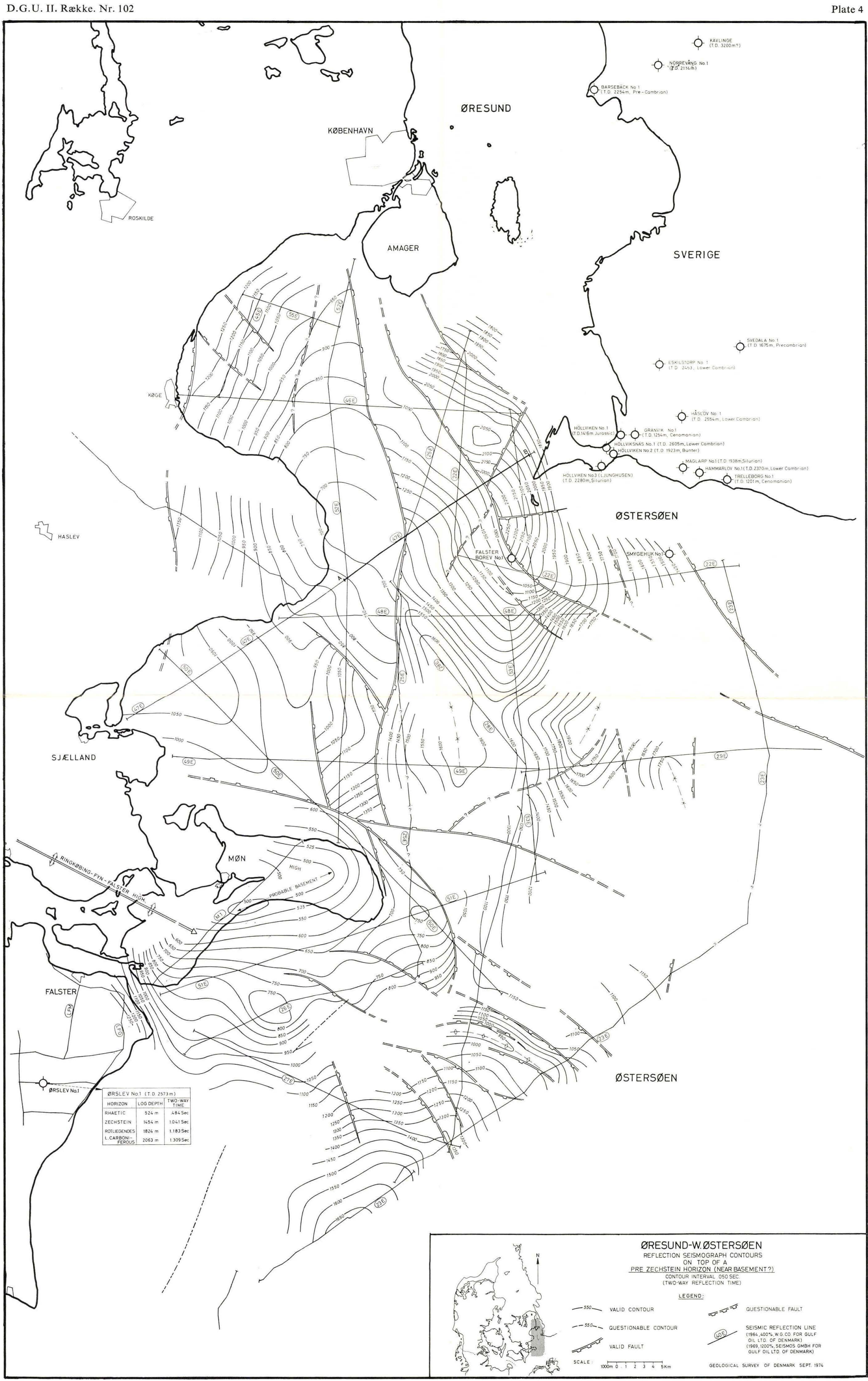

